Atıf Bilgisi: Baydili, İ. ve Çetin, B. N. (2021). Darbeden harekâta Kıbrıs: Kıbrıs Barış Harekâtına yönelik kamuoyu oluşum sürecinde yazılı basının rolü. INIIF E- Dergi, 6(2), 386-408.

\title{
DARBEDEN HAREKÂTA KIBRIS: KIBRIS BARIŞ HAREKÂTINA YÖNELİK KAMUOYU OLUŞUM SÜRECINDE YAZILI BASININ ROLÜ*
}

\author{
$\ddot{O} \breve{g r}$. Gör. Dr. İsmail BAYDILLI $\dot{I}^{* *}$ \\ Doç. Dr. Beyzade Nadir ÇETIN ${ }^{* * * *}$ \\ DOI: 10.47107/inifedergi.878608
}

Araștırma Makalesi

Başvuru Tarihi: 11.02.2021

Kabul Tarihi: 30.04.2021

Öz

Kitle iletişim araçlarının üzerinde durulması gereken önemli yönlerinden birisi kamuoyu oluşturma gücüdür. Kamuoyuna sürekli bilgi aktaran bu araçlar doğal olarak kamuoyunda önemli bir etkiye sahiptir. Bu etki dönem dönem iktidarların istek ve beklentilerini kamuoyuna aktarmada da kullanılmıştır. Ayrıca iktidarların istek ve beklentilerine uygun kamuoyu algısı oluşturmada ya da kamuoyundaki algının iktidarların istek ve beklentilere göre yönlendirilmesinde de kullanılmıştır. $\mathrm{Bu}$ amaçlarla kullanımlar didaktik yöntemlerden ziyade genellikle farklı amaçlarla hazırlanmış çeşitli öğelerin içine yerleştirilerek gerçekleştirilmiştir. Böylece aktarılmak istenilen mesajlara direnç oluşumunun önüne geçilerek en üst düzeyde kitleye ulaşma amaçlanmıştır. Türkiye de çeşitli dönemlerde kamuoyuna iktidar mesajlarını aktarmada bahsedilen yöntemi kullanmıştır. Türkiye için bu dönemlerden birisi de Kıbrıs Barış Harekâtı dönemidir. Kıbrıs Barış Harekâtının öncesi, harekât esnası ve harekât sonrası iktidar tarafından çeşitli bilgi ve mesajlar kamuoyuna aktarılmıştır. Mesajların ilk muhatapları Türk kamuoyu olsa da mesajlar, uluslararası amaçlara da hizmet eden öğeler içermektedir. Bu mesajlar açık bir yöntemle değil, çeşitli kodlamalarla gerçekleştirilmiştir. Bu çalışmada Kıbrıs Barış Harekâtının başlamasında büyük bir etkiye sahip olan Makarios'a karşı yapılan darbeden itibaren, harekât gününe kadar geçen dört günlük süreçteki gazeteler incelenmiştir. Gazeteler aracılığı ile Türk ve dünya kamuoyuna hangi mesajların açık, hangi mesajların satır aralarında aktarıldığı eleştirel jeopolitik açıdan tespit edilmeye çalışılmıştır. Çalışmada yöntem olarak içerik analizi yöntemi kullanılmıştır. Elde edilen veriler, eleştirel jeopolitik bakış açısı ile değerlendirilmiştir. Değerlendirme sonucunda elde edilen bulgulara göre, gazetelerde öncelikle Türk kamuoyuna Kıbrıs'a neden müdahale edilmesi gerektiği aktarılmıştır. Müdahale edilmediğinde olası sonuçlar ve Türkiye'nin göreceği zararlar anlatılmıştır. Dünya kamuoyuna ise Türkiye'nin Garantör devlet olarak Kıbrıs’ta bozulan düzeni yeniden kurmak istediği anlatılmıştır. Katledilen Rum ve Türk halkını kurtarmanın Türkiye’nin garantörlük görevi olduğu izah edilmiştir.

Anahtar Kelimeler: Eleştirel Jeopolitik, Kıbrıs, İletişim Sosyolojisi, Tasavvur Oluşturma, Gazete Analizi.

\section{CYPRUS FROM COUP TO OPERATION: THE ROLE OF THE PRINT MEDIA IN THE PUBLIC OPINION PROCESS FOR THE CYPRUS PEACE OPERATION}

\section{Abstract}

One of the significant aspects of mass media that must be emphasized is its power to generate public opinions. These tools, which constantly transmit information to the public, spontaneously have an important impact on public opinion. This effect was also used to convey to the public the demands and expectations of the government from time to time It has also been used to create public perception in accordance with the demands and expectations of the government or to direct public perception in accordance with the demands and expectations of the government. Uses aimed at these purposes were usually carried out by adding various elements that are generally

\footnotetext{
* Bu çalışma, Fırat Üniversitesi, Sosyal Bilimler Enstitüsü, Sosyoloji ABD’de Doç. Dr. Beyzade Nadir Çetin danışmanlığında hazırlanan "Eleştirel Jeopolitik Yaklaşım Çerçevesinde Kıbrıs Barış Harekatı: Gazetelerin İncelenmesi (Hürriyet, Milliyet, Cumhuriyet, Milli Gazete)" başlıklı doktora tezinden üretilmiştir.

** Fırat Üniversitesi, TBMYO, Görsel-İşitsel Teknikler ve Medya Yapımcılığı Bölümü, E-mail: ibaydili@firat.edu.tr, ORCID: 0000-0001-8563-8342 ${ }^{* * *}$ Frrat Üniversitesi, İnsani ve Sosyal Bilimler Fakültesi, Sosyoloji Bölümü, E-mail: bnadircetin@ firat.edu.tr, ORCID: 0000-
0002-4560-1331

***** Yazar / yazarlar, makalede araştırma ve yayın etiğine uyulduğuna ve kullanılan fikir ve sanat eserleri için telif hakları düzenlemelerine riayet edildiğine yönelik beyanda bulunmuştur.
} 
prepared for different purposes rather than didactic methods. This way, it was aimed to reach the highest level of audience by preventing resistance to the messages to be conveyed. Turkey has also used the method mentioned above in conveying government messages to the public in various periods., One of those periods is the Cyprus Peace Operation. Various information and messages were conveyed to the public by the government before, during and after the Cyprus Peace Operation. Although the messages are aimed at the Turkish public, the messages contain elements that also serve international purposes. These messages were not carried out explicitly, but by various encodings. This study examined the newspapers in the four-day period from start of the coup against Makarios, who had a great impact on the Cyprus Peace Operation, until the day of the operation Through the newspapers, it was tried to ascertain which messages were open to the Turkish and world public and which messages were transferred between the lines from a critical geopolitical point of view. content analysis was used as the method of the study. The data obtained as a result of the method were evaluated with a critical geopolitical perspective. Findings obtained from the study were interpreted. According to the interpretation, in the newspapers; First of all, it was conveyed to the Turkish public the need for an intervention in Cyprus. Possible consequences and the damages that Turkey will suffer when there is no intervention were explained. And to the world public, it was conveyed that Turkey, as a guarantor state, wants to re-establish the deteriorating order in Cyprus. It was explained that it is Turkey's duty as a guarantor to guarantee the safety of the Greek and Turkish people being slayed. Analysis.

Keywords: Critical Geopolitics, Cyprus, Communication Sociology, Identity Construction, Newspaper

\section{Giriş}

Topluma hitap eden, toplumu yönlendirmek ya da etkilemek isteyen bütün alanlar öncelikle kitle iletişim araçlarını kullanmayı amaçlamıştır. Jeopolitik de bu alanlardan birisidir. Jeopolitik bilimi, coğrafi bilgilerin ötesinde siyasi, ekonomik ve kültürel öğeleri de içinde barındıran bir bilim dalıdır. Tarihin değişik dönemlerinde jeopolitik bilimi ile ilgili farklı düşünceler oluşmuştur. I. Dünya Savaşı'na kadar saygın bir bilim olarak görünen jeopolitik I. Dünya Savaşı'ndan sonra daha çok saldırgan ve yayılmacı bir politikanın bilimi olarak görülmüştür. II. Dünya Savaşı ise jeopolitik algıyı tekrar şekillendirmiş ve devletlerin rekabetinde jeo-stratejinin gelişmesini sağlamıştır (Yeşiltaş, 2016, s. 61). II. Dünya Savaşından sonraki dönemlerde, özellikle Anglo Sakson dünya jeopolitik tahayyülleri önemli bir noktaya taşımış ve o güne kadar gelen klasik jeopolitiğin eleştirilerini yaparak "Eleştirel Jeopolitiğin" oluşumunu sağlamıştır (Tezkan ve Taşar, 2013, s. 240).

Eleştirel jeopolitiğin adından da anlaşılacağı gibi o güne kadar süregelen jeopolitik yönteme karşı bir eleştirisi vardır. Bu eleştirilerini ağırlıklı olarak iktidar merkezli bilgi üretimi ve dağıtımına yönlendirmiştir. İktidar tarafından oluşturulan bilginin güvenilirliği sorununu gündeme getirerek kitlelere aktarılan bilgilerin, kitleler tarafından sorgulanmasını tavsiye etmiştir. Özellikle kitle iletişim araçlarında yoğun ve gizli bir iktidar söyleminin varlığından bahsetmiştir ${ }^{1}$.

Eleştirel jeopolitiğe göre kitle iletişim araçlarında yaşanan hızlı gelişim ve dönüşümün sağladığı avantajlar jeopolitik anlayış tarafından kullanmaktadır. Kitle iletişim araçlarının hem hızlı ve geniş kitlelere ulaşabilme potansiyeli hem de insanlar üzerinde etki bırakma gücü jeopolitik için önemli bir araç olmasını sağlamaktadır. Ayrıca internet, Tv gibi hızlı iletişim araçları, meydana gelen olaylarda istenileni ön plana alabilirken, istenileni de geri plana atabilmekte böylece gündemi belirleyebilme potansiyelini de elinde tutmaktadir ${ }^{2}$ (Tirben, 2009, s. 232-236). Eleştirel jeopolitiğe göre oluşturulan gündemlerde açık ya da gizli mesajlarla iktidar

\footnotetext{
${ }^{1}$ Eleştirel jeopolitiğin gelişmeye başladığı dönem, post-modern etkinin yükseldiği eleştirel bakış açılarının rövanşta olduğu bir dönemdir (Yeşiltaş, 2016, s. 51). Böyle bir dönemde gelişen bu düşünce, klasik jeopolitiğin topografik sınırlarının ötesine geçerek yeni bir bakış açısı kazandırmıştır. Eleştirel jeopolitik o döneme kadar yaygın jeopolitik düşüncelerin ötesinde jeopolitiği güç-bilgi ilişkisi ile siyasi ve sosyal ilişkiler üzerinde oturtan bir söylem olarak değerlendirmiştir (Dodds, 2000, s. 33). Eleştirel jeopolitiğin kurucusu olarak kabul edilen Ó Tuathail, bu düşünceyi açıklarken kültürel politikaların karmaşıklığını çözmeyi ön planda tutmuş, klasik jeopolitiğin sakladığı bilgi ve ilişkilerin ortaya koyulmasını da amaç olarak ifade etmiştir (Ó Tuathail, 1999, s. 107-108). Eleştirel jeopolitiğin bir diğer önemli düşünürü Dodds ise dünya siyasetinin kara ve denizin ilahi yapısından daha fazlası olduğunu belirterek siyasetin yorumlanmasını ve incelenmesini gerekli gördüğünü ifade etmiştir (Dodds, 2005, s. 29).

2 "Gündem Belirleme Kuramı" (McCombs ve Shaw) olarak ifade edilen bu kurama göre göre, kitle iletişim araçlarının belirledikleri gündemler beraberinde kamuoyunun da gündemi haline gelmektedir (McQuail ve Windahl, 1994, s. 95).
} 
söylem ve istekleri kamuoyuna aktarılmakta, böylece kamuoyunda bir tasavvur oluşturulmaktadır.

Eleştirel jeopolitik için en önemli unsur, tasavvur oluşturmadır. Jeopolitik bir düşünüşün oluşup gelişmesi ve yaygınlaşması ile jeopolitik bir muhakemenin oluşması tasavvur ile açıklanmaktadır (Çetin, 2017, s. 327). Bu tasavvurların kitlelere buluşması, kitleler tarafından anlaşılıp algılanması ise kitle iletişim araçları aracılığı ile gerçekleşmektedir. Eleştirel jeopolitik düşünce, kitle iletişim araçlarının tasavvur oluşturma becerisine verdiği önem, eleştirel jeopolitiğin üç alt başlığından birisini almasını sağlamıştır ${ }^{3}$. Popüler jeopolitik olarak ifade edilen bu başlık, dergi, gazete, karikatür, roman, Tv, sinema gibi kitle iletişim araçlarındaki jeopolitik akıl yürütmeyi inceleyen alandır. Dodds, popüler jeopolitiğin medya aracılığı ile dünya politikalarının üretilmesi ve üretilen politikaların yeniden üretilmesinde gündem oluşturucu, anlatıların yerleşmesinde şekillendirici, kimliklerin inşasında yerleştirici rolünden bahsetmektedir (Şener, 2017, s. 169). Dodds'tan yola çıkarak popüler jeopolitiği daha yalın ifade edecek olursak; tasavvur, temsil ve pratiklerin popüler kültür araçlarında üretilmesi ve tüketilmesi olarak da ifade edebiliriz (Yeşiltaş ve Durgun, 2015, s. 28).

Özetle popüler jeopolitiğe göre popüler kültür unsurları iktidarların söylem ve pratikleri ile birlikte ele alınmalıdır. ABD yetkilileri tarafından 11 Eylül saldırılarından sonra Hollywood sinemasının "kader günü" olarak ifade edilen saldırılarla alakalı filmlerin hazırlanması ya da gündemi değiştirecek filmlerin vizyon tarihlerinin ertelenmesi (Dodds, 2008, s. 482-483) bu düşüncenin en iyi örneklerindendir. Örnekten anlaşıldığı gibi popüler söylemler, popüler kültür araçları ile aktarılabilmektedir. Popüler jeopolitiğe göre kitlelerin düşüncelerini yönlendirmek kadar iktidarın düşüncelerini de kitlelere empoze etmek önemlidir. ABD basınından yola çıkıldığında sadece Hollywood filmlerinde değil, birçok Tv programlarında da ABD politikalarının aktarıldığı görülmektedir. Böylece sürekli iktidar ifadelerine maruz kalan kitlenin karmaşık jeopolitik konuları dahi daha rahat anlaması sağlanmaktadır (Anaz, 2012, s. 30-31).

İktidar söylemlerinin kitle iletişim araçları ile aktarılmasını analiz eden bu çalışma, kitle iletişim araçlarındaki öğelerin tesadüfen yerleştirilmediğini birçoğunun belirli amaçlarla tasarlandığını gözler önüne sermek istemektedir. Eleştirel jeopolitik yöntemlerin kitle iletişim araçlarındaki kullanımını kontrol edip, kimlik ve mekân inşalarını tespit etmek amacıyla Kıbrıs Barış Harekâtına yönelik açık ve örtülü mesajları incelenmektedir. Böylece Kıbrıs Barış Harekâtını gerçekleştirirken 37. Hükümetin Türk ve dünya kamuoyuna aktardığı mesajlar eleştirel jeopolitik çerçevede değerlendirilecektir.

$\mathrm{Bu}$ çalışmayı diğer araştırmalardan özgün kılan durum iktidarın bir eylemi gerçekleştirirken kamuoyu oluşturma amacıyla eleştirel jeopolitik yöntemleri kullanmasını incelemesidir. Bu incelemeyi de tek bir öğe üzerinden gerçekleştirmeyip, belirli bir zaman aralığında, birden fazla kitle iletişim aracında gerçekleştirmektedir. Kısaca, çalışmanın yeni bir bakış açısı geliştirebileceği düşünülmektedir. Bu çalışmayla, "Türkiye Kıbrıs Barış Harekâtını gerçekleştirirken, yazılı basın üzerinden iç ve dış kamuoyuna yönelik eleştirel jeopolitik bir yöntem kullanmış mıdır?" sorusuna yanıt aranmıştır. Ayrıca bu temel soruyla birlikte bu araştırmada bazı alt sorular da incelenmiştir. İncelenilen alt sorular:

Yazılı basındaki haberlerde:

- Kıbrıs Devleti'nin Garantörlerine (Türkiye, İngiltere ve Yunanistan) yönelik bir kimlik inşası var mıdır?

- Garantör devletler dışında başka bir devlete yönelik kimlik inşası var mıdır?

\footnotetext{
${ }^{3}$ Eleştirel jeopolitiğin kurucu metinlerinde üç ana türden bahsedilmektedir. Formel, pratik ve popüler jeopolitik olarak ifade edilen bu türlerin kaynakları, yöntemleri ve yapıları birbirlerinden farklıdır (Tezkan ve Taşar, 2013, s. 256). Formel jeopolitik, akademisyenler ve düşünce kuruluşları tarafindan üretilmektedir (Ó Tuathail, 1998, s. III) ve söylem üreten entelektüellerin antidemokratik ve determinist söylemleri ile ilgilenen, entelektüellerin düşünce biçimlerine göre şekillenen (Dodds ve Atkinson 2000; Yeşiltaş ve Durgun, 2015, s. 27) bir alandır. Pratik jeopolitik ise daha çok karar vericilerin (liderler, dış politika uzmanları, bürokratlar vs.) söylemlerini kapsayan (Ó Tuathail ve Agnew, 1992, s. 193) alandır.
} 
- $\quad$ Dönemin Türkiye yöneticilerine yönelik bir kimlik inşası var mıdır?

- Dönemin yabancı devlet adamlarına yönelik bir kimlik inşası var mıdır?

- Uluslararası kuruluşlara yönelik bir kimlik inşası var mıdır?

- Kibrıs'a yönelik bir mekân inşası var mıdır?

- Kıbrıs'a yönelik bir tahayyül oluşumu var mıdır?

Sorularına yanıt aramak için yöntem kısmındaki kategoriler belirlenmiştir.

\section{Kıbrıs'ın Konumu, Önemi ve Darbe Dönemine Kadar Kıbrıs'ta Meydana Gelen Önemli Gelişmeler}

Türkiye'nin 70 km güneyinde bulunan, Akdeniz'in beşinci büyük adası Kıbrıs (Bulunç, 2016, s. 1-3) jeopolitik ve jeostratejik olarak tüm hâkimiyet teorilerinin kapsamına giren önemli bir kara parçasıdır. Kıbrıs'ın önemini sadece dünya üzerindeki konumu ile ölçmek hatalı olacaktır. Kıbrıs konumun getirdiği avantajların yanında stratejik açıdan da oldukça kıymetlidir. Özellikle petrol kaynaklarına yakınlığı, Ortadoğu, Afrika, Süveyş Kanalı ve Anadolu gibi geniş eksenli bir etki alanına sahip olması (Cankurt, 2013, s. 10) Kıbrıs'ın her dönem önemini korumasını sağlamıştır. Teknolojik gelişmeler, dünyadaki ticaret yöntemlerinin değişmesi bile Kıbrıs'ın öneminin azalmasına neden olamamıştır (Bulunç, 2016, s. 33-35).

Kıbrıs bu özellikleri ile tüm dünya için önemliyken, Türkiye için daha da büyük bir öneme sahiptir. Çünkü Kıbrıs’ta meydana gelecek bir değişikliğin Türkiye üzerinde de büyük etkileri olacaktır. Kıbrıs'ın Türkiye açısından düşman ya da rakip bir gücün elinde olması Türkiye'nin Akdeniz'deki hareket alanını daraltacağı gibi Türkiye'nin güvenliğini de ciddi bir tehlikeyle karşı karşıya koyacaktır (Turan, 2009, s. 512). Olası bir savaş veya gerginlik durumunda Akdeniz'deki kontrolünü kaybedecek olan Türkiye, Kıbrıs'ta konumlandırılmış bir güç tarafından vurulabilecek ve ağır kayıplara uğramasına olanak tanıyabilecektir (Cankurt: 2013, s. 11). Kıbrıs tarihinin Anadolu tarihi ile paralel gitmesi adanın Anadolu için ne kadar önemli olduğunun bir göstergesidir. Alman bilim insanı Dümmler'in araştırmaları Anadolu medeniyetleri ile Kıbrıs'ın münasebetini açıkça ortaya koymuştur (Erzen, 1963, s. 162). Tarihin değişik dönemlerinde Kıbrıs'ın iktidar güçleri de değişmiştir. Mısırlılar, Hititliler, Akadlılar, Dorlar, Finikeliler, Asurlular, Persler, Romalılar, Araplar, Lüzinyanlar (Fransızlar), Cenevizliler, Venedikliler (İtalyanlar), Osmanlılar, İngilizler belirli dönemlerde adaya sahip olmuştur (Cankurt, 2013, s. 5).

Kıbrıs'ın ilk defa Türk hâkimiyetine girmesi Osmanlı dönemindedir. Osmanlı Devleti'ni Kıbrıs için harekete geçiren sebep Akdeniz'in güvenlik sorunudur. Ayrıca Yavuz Sultan Selim'in Mısır'ı Osmanlı topraklarına katması Osmanlı açısından Kıbrıs'ın önemini daha da artırmıştır. Venediklilerin vergilerini vermemesi, ticaret gemilerine zarar vermeleri ve Osmanlı'nın Hac güzergâhını güvence altına alma isteği Kıbrıs'a fetih harekâtı başlatmasını sağlamıştır (Ekincikli, 1999, s. 480-481). II. Selim döneminde Kıbrıs Osmanlı topraklarına (1570-1571) katılmıştır (Akmaral, 2004, s. 42). Osmanlı Devleti'nin adaya hâkimiyeti o döneme kadar Katolik Venediklilerin eziyetine uğrayan Ortodoks Kıbrıslıların da rahatlamasını sağlamış ve ada tarihinde ilk defa Rumlar adada söz sahibi hale gelmiştir (İsmail, 1998, s. 1). Osmanlı dönemi Kıbrıs için en uzun huzur dönemi olmuştur. Ada sakinlerinin can, mal ve namus güvenliği sağlanmıştır (Mütercimler, 2003, s. 56). Osmanlı Kıbrıs'ın kalıcı bir şekilde Türk yurdu olması için iskân politikası da uygulamış, Anadolu'nun çeşitli yerlerinden Türkleri Kıbrıs'a zorunlu göç ettirmiştir (Gerçel, 1999, s. 488). Osmanlı idaresinde Kıbrıs ticari ve jeopolitik açıdan değerli bir hale gelmiş, Kıbrıs'ın bu hali birçok devletin ilgisini çekmiş ve adada konsolosluk açmalarını ya da konsolos vekili bulundurmalarını sağlamıştır (Erdoğru, 1999, s. 315-317).

Adanın önemi 1800'lü yıllarda Süveyş Kanalı'nın açılması ile daha da artmış, İngiltere'nin gözünü Kıbrıs'a dikmesine neden olmuştur. İngiltere adayı ele geçirmek için aradığı firsatı Rus-Osmanlı savaşı sonrası imzalanan Ayastefanos (1877-1878) Anlaşması 
ardından bulmuştur. İngiltere, Osmanlı Devleti'ne Rus ilerleyişine karşı yardım teklifinde bulunmuş, karşıllığında ise mülkiyet hakkı Osmanlı Devleti'nde olmak şartıyla adanın İngiltere'ye devredilmesini talep etmiştir (Mütercimler, 2003, s. 56-57). Yapılan anlaşmayla İngiltere, Rusya'nın Osmanlı topraklarına tekrar saldırması durumunda birlikte karşı koymayı kabul etmiş ve Rusya'nın Kars ve diğer işgal ettiği yerleri geri vermesi durumunda İngiltere'nin de Kıbrıs'ı geri vereceği kararlaştırılmıştır (Çakmak, 2009, s. 18). Adanın böyle bir oldubitti ile el değiştirmesi uzun yıllar adada barış ve huzur içinde yaşayan Rumların, Yunanistan'a ilhak ihtimalinin oluştuğu düşüncesi ile memnuniyetle karşılanmıştır. Rumların ilhak düşünceleri (ENOSİS) özellikle Osmanlı'nın zayıfladığı 1911 ve 1912 yıllarında daha da artmıştır (Kurşun, 1999, s. 1-6). 1914 yılında başlayan Birinci Dünya Savaşı ve ardından gelen Kurtuluş Savaşı dönemi Osmanlı Devleti'nin zor günler geçirmesine neden olurken, Kurtuluş Savaşı sonrası kazanılan zaferin ardından imzalanan Lozan Barış Antlaşması'nda Kıbrıs'ın mülkiyet hakkı da İngiltere'ye devredilmiştir (İsmail, 1998, s. 9).

Adanın mülkiyet hakkının İngiltere'ye geçmesi adanın Türk ve Rum nüfusu ile Türkiye ve Yunanistan arasında uzun yıllar sürecek olan, birçok kanlı olayın yaşandı̆̆ "Kıbrıs Meselesi" için de önemli bir dönüm noktasıdır. II. Dünya Savaşı sonrası değişen dünya İngiltere'nin sömürgelerinden çekilmesine neden olmuş (Manisalı, 2000, s. 27), bu durum Kıbrıslı Rumların ENOSİS düşüncelerini daha da körüklemiştir. Fakat adadaki varlığını devam ettirmek isteyen İngiltere (Hasgüler, 2007, s. 39-40) o döneme kadar Kıbrıs ile ilgili fikir beyan etmekten çekinen Türkiye'nin Kıbrıs konusuna müdahil olmasını sağlamıştır. Türkiye artık Kıbrıs'ta hak iddia eder bir pozisyona geçmiştir (Manizade, 1965, s. 96).

1956 yılında dönemin Başbakanı Adnan Menderes “Ada, İngilizlerde kalsın; İngilizlerden çıkarsa bize verilsin, Bu olmazsa taksim edilsin” diyerek Türkiye'nin Kıbrıs politikasını açıkça ifade etmiştir (Hasgüler, 2007, s. 39-40). Adanın iç karışıklıkları devam ederken 1959 yılında Yunanistan ve Türkiye'nin uzlaşması ile Zürih şehrinde anlaşma imzalanmıştır (Bulunç, 2016, s. 123). Bu anlaşmaya göre Kıbrıs Cumhuriyeti kurulmuştur (Mütercimler, 2003, s. 110). Anlaşmayı İngiltere, adadaki Türk ve Rum temsilcilerin yanı sıra anavatan statüsü ile Yunanistan ve Türkiye de imzalamıştır (Manisalı, 2000, s. 35). Bu anlaşmanın haricinde imzalanan Garanti Antlaşması da Kıbrıs'ın geleceğine yön veren önemli bir aşamadır. Türkiye'nin Kıbrıs'a yönelik yaptığı tüm müdahalelerin kaynağı statüsünde olan Garanti Anlaşması'na göre Türkiye ve Yunanistan adadaki düzenin bozulması durumunda adaya müdahale ederek düzenin yeniden kurulmasını sağlayabilecektir (İsmail, 1998, s. 53-54).

Kıbrıs Cumhuriyeti'nin kurulması ile adanın 82 yıllık İngiltere yönetimi sona ermiş Makarios'un Cumhurbaşkanlığı ve Fazıl Küçük'ün Cumhurbaşkanı Yardımcılığında yeni bir dönem başlamıştır (Bulunç, 2016, s. 127). Kurulan devlet Kıbrıs'ta yaşanan sorunların sona ermesini sağlayamamış, aksine ENOSİS düşüncesinin daha da güçlenmesine neden olmuştur (Akmaral, 2004, s. 105-106). 1963 yılında gerçekleşen "Kanlı Noel” olarak bilinen saldırılarda birçok Kıbrısı Türk katledilmiştir. Saldırılar karşısında Türkiye savaş uçaklarını Lefkoşa'ya göndererek Rumların saldırıları sonlandırmasını sağlamıştır (Açıkses ve Cankurt, 2014, s. 1250). 1974 yılında Türkiye'nin adaya müdahalesine kadar çeşitli dönemlerde tekrarlanan bu saldırıları gerçekleştiren EOKA örgütü, Yunanistan ile Makarios'un ilişkilerinin bozulması ile Rumlar arasında bir iç savaşın yaşanmasına da neden olmuştur. EOKA ile Makarios'un mücadelesi devam ederken EOKA lideri Grivas'ın ölmesi adadaki dengelerin değişmesine neden olmuştur. Adada tek güç haline gelen Makarios'un bu konumu Yunanistan'1 rahatsız etmiş ve Makarios'u devirmek için darbe planları yapılmaya başlanmıştır (Sonyel, 2014, s. 6-23). 2 Temmuz 1974 tarihinde Makarios'un Yunan Cunta Yönetimine gönderdiği mektup Yunanistan ile Makarios'un aralarındaki sorunların açıkça ortaya çıkmasını sağlamıştır (İsmail, 1998, s. 121-124). Makarios kendisine karşı darbe girişiminde bulunulacağını açıkça ifade etmesine rağmen bu düşünce İngiltere ve ABD tarafindan pek rağbet görmemiştir. 15 Temmuz 1974 tarihinde gerçekleşen darbe devam ederken, darbeyi gerçekleştiren EOKA örgütü tarafından Makarios'un yerine Sampson yeni cumhurbaşkanı olarak atanmıştır. Sampson'un cumhurbaşkanı olarak atanması 
adanın Türk nüfusunun ve Türkiye'nin büyük tepkilerine yol açmıştır. Çünkü atanan Sampson Türk katili olarak bilinmektedir. Türklere yönelik birçok kanlı eylemin sorumlularındandır. Rauf Denktaş Sampson'un atamasını “İsrail'e Hitler'in Cumhurbaşkanı atanması" olarak değerlendirmiştir (Sonyel, 2014, s. 23-68). Sampson Türkiye'nin olası bir müdahalesini önlemek için Denktaş'ın Cumhurbaşkanı yardımcısı olarak devam edeceğini açıklamıştır. Ayrıca Türklere yönelik hiçbir eylemin yapılmayacağını da beyan etmiştir (Denktaş, 1999, s. 365). Adadaki Türk nüfusu bu durumdan oldukça rahatsız olmuş, can ve mal güvenlikleri tehlikeye girmiştir. Türkiye adadaki Türk nüfusunun güvenliğini sağlamak ve adanın düşman bir güç tarafindan işgal edilmesini önlemek amacıyla birçok diplomatik girişimde bulunmuştur.

\section{2. Çalışmanın Amacı ve Sınırlılıkları}

Giriş bölümünde ifade edilen "Türkiye Kıbrıs Barış Harekâtını gerçekleştirirken, yazılı basın üzerinden iç ve dış kamuoyuna yönelik eleştirel jeopolitik bir yöntem kullanmış mıdır?” sorusuna yanıt bulabilmek bu araştırmanın temel amacıdır. Bu sorunun cevaplanabilmesi için öncelikle Kıbrıs Barış Harekâtını gerçekleştiren iktidarın (37. Hükümet) gazeteler aracılığı ile Türk ve dünya kamuoyuna aktardığı açık ve örtülü mesajlar ortaya konulmuştur. Böylece gazeteler aracılığı ile oluşturulan temsil, tasavvur ve kimlik inşalarının anlaşılması sağlanılmıştır. Çalışmanın evreni dört gazete (Cumhuriyet, Hürriyet, Milliyet ve Milli Gazete) ile sınırlandırılmıştır. Cumhuriyet ve Milli Gazete dönemin hükümetini oluşturan CHP ve MSP partilerine olan yakınlıklarından ötürü tercih edilmiştir. Hürriyet ve Milliyet Gazetelerinin tercihi ise dönemin tirajları en yüksek ana akım gazetelerinden olmaları ve herhangi bir ideoloji ile hareket etmemeleridir. Hem iktidara yakın hem de ana akım gazetelerin aralarındaki bakış farkının da gözler önüne serileceğine olan inançla hareket edilmiştir. $\mathrm{Bu}$ gazetelerin sadece birinci sayfa haberleri analiz edilmiştir. Çünkü gazeteler ilk sayfalarında en öncelikli konuları sunarlar. İlk sayfalar vitrin statüsündedir ve gazetenin tüm içeriği ile ilgili bilgi aktarır (Tiryakioğlu ve Top, 2010, s. 140).

Çalışmanın zaman sınırlılığı 16-17-18-19 Temmuz 1974 tarihli gazeteler olarak belirlenmiştir. Zaman aralığı olarak bu dört günün seçilmesi, Kıbrıs Devleti Cumhurbaşkanı Makarios'a karşı yapılan darbenin 15 Temmuz 1974 tarihinde gerçekleşmesinden dolayıdır. 15 Temmuz tarihinde yaşanan olağandışı durum Kıbrıs'ın bir anda çok yoğun bir şekilde gündeme gelmesini sağlamış ve 20 Temmuz 1974 tarihinde de Türkiye Kıbrıs'a harekât düzenlemiştir. Bu iki tarih aralığında Kıbrıs, gazetelerin manşetlerinden hiç düşmemiştir. $\mathrm{Bu}$ nedenlerle zaman sınırlılığı 16-19 Temmuz olarak belirlenmiştir.

\section{Yöntem}

Çalışmada, nitel araştırma deseni kullanılmıştır. Çalışmada gazetelerin analizi, içerik analizi yöntemi ile gerçekleştirilmiştir. İçerik analizi, televizyon programları, romanlar, filmler politik konuşmalara uygulanabilindiği gibi gazete içeriklerinin analizine de uygun bir yöntemdir (Neuendorf, 2002; Yıldırım, 2015, s. 105). Konuyla ilgili metinlerin araştırılmasında ve anlaşılmasında kullanılan bu yöntemde öncelikle araştırmanın problemi belirlenir. İkinci aşamada ise araştırmanın soruları ve hipotezleri oluşturulur. Çözümleme birimleri, örneklemin belirlenmesi ve kategorilerin oluşturulmasının ardından kodlama ve sonuç kısmı ile sonlandırılır (Y1ldirım, 2015, s. 126).

İçerik analiziyle söylemlerin anlaşılması ve yorumlanmasında öznel etkilerden kurtulmak ve söylemlerin ilk bakışta anlaşılan anlamlarından ziyade gizil, üstü örtülü anlamlarını ortaya çıkarma amaçlanmıştır (Bilgin, 2014, s. 1). "Bir anlamda toplanan verilere dayalı bir 'okuma' aracı olarak" (Arğın, 2019, s. 400) değerlendirilmiştir. Araştırmada içerik analiz tekniklerinden, kategorisel analiz tekniği kullanılmıştır. Bu tekniğe göre öncelikle kategoriler hazırlanmış, kategorilere uygun anlam birimleri, saptanan kategorilere yerleştirilmiştir (Bilgin, 2014, s. 20).

İçerik analizi yönteminde kullanılan kategorilendirme daha önceden geliştirilmiş olabileceği gibi yeniden bir kategorilendirme sistemi de geliştirilebilir. Kategorilerin 
oluşturulmasında homojenliğe, objektifliğe, amaca uygunluğa, anlamlı ve araştırma ile ilişkili olmasına dikkat edilir. Ayrıca kategorilerin birbirleri ile çakışmaması da sağlanmalıdır (Aslan ve Tavşanc11, 2001; Pınarbaşı, 2020, s. 186).

Çalışmada kullanılan yedi kategori belirlenmiştir. Kategoriler belirlenirken teorik formasyona uygunluk göz önünde tutulmuştur. Kategoriler saptandıktan sonra, mesaj öğelerinin kategorilere yerleştirilmesi yapılmıştır (Bilgin, 2014, s. 13). Çalışmada hazırlanan kategoriler ve kategorileri oluşturan anlam birimleri Tablo 1'de verilmiştir. İçerik analizi yöntemi ile oluşturulan kategoriler sonucunda elde edilen veriler tablolaştırılmıştır. Oluşan tablolar, incelenen kavramların kullanım sıklıklarını göstermektedir. İçerik analizi yöntemi ile elde ettiğimiz veriler sonuç ve tartışma kısmında eleştirel jeopolitik bakış açısı ile yorumlanmıştır.

Tablo 1. Çalışmada Oluşturulan Kategoriler ve Anlam Birimleri

\begin{tabular}{|l|l|} 
Kategoriler & \multicolumn{1}{|c|}{ Anlam Birimleri } \\
\hline Garantör Devletler & $\begin{array}{l}\text { Garantör Devletler, Türkiye (Türk Devleti, Ankara), İngiltere (Birleşik Krallık, Londra), } \\
\text { Yunanistan (Atina, Cunta Yönetimi/Hükümeti) }\end{array}$ \\
\hline Diğer Devletler & $\begin{array}{l}\text { ABD (USA, Amerika Birleşik Devletleri, Birleşik Devletler, Washington), SSCB (Sovyetler } \\
\text { Birliği, Moskova) }\end{array}$ \\
\hline $\begin{array}{l}\text { Uluslararası } \\
\text { Kuruluşlar }\end{array}$ & BM, NATO \\
\hline Türk Yöneticiler & $\begin{array}{l}\text { Bülent Ecevit, Necmettin Erbakan, Semih Sancar, Hasan Esat Işık, Fahri Korutürk, Turan } \\
\text { Güneş, Rauf Denktaş }\end{array}$ \\
\hline Yabancı Yöneticiler & $\begin{array}{l}\text { Joseph John Sisco, Henry Kissinger, Harold Wilson, Kurt Waldheim, Joseph Luns, James } \\
\text { Callaghan, Richard Nixon }\end{array}$ \\
\hline Örgütler & Cunta, Enosis, Eoka \\
\hline Aktarım Yöntemleri & Kibrıs Olayları, Milli Dava, Kıbrıs Sorunu, Kıbrıs Meselesi \\
\hline
\end{tabular}

Kitle iletişim araçlarında görülen ve kitlelerin hayatını etkileyen birçok öğe tesadüfi olarak yerleştirilmemektedir. Bir amaç doğrultusunda bazen algıları güçlendirmek, bazen yeni bir algı oluşturmak amacıyla tasarlanmaktadır. Bu düşünce ile hareket eden eleştirel jeopolitik bakışta, kitle iletişim araçlarını analiz ederek "kimlik ve mekân” inşalarının nasıl gerçekleştiğini ortaya çıkarma amaçlamaktadır. Bu bağlamda çalışmada, kimlik tasavvuru kapsamında sonuç bölümünde; Türk tasavvuru, Yunan tasavvuru, Rum tasavvuru oluşumları ele alınmıştır. Mekân tasavvuru oluşumunda ise Kıbrıs, Türkiye ve Yunanistan tasavvuru incelenmiştir. Ayrıca Türkiye'nin Kıbrıs politikasını izah noktasında kullandığı bazı kilit kavramlar araştırılmış ve yorumlanmıştır.

\section{Bulgular ve Yorum}

Tablo.1'de belirlenmiş olan kategorilere göre ilgili gazetelerin birinci sayfaları incelenmiş ve kavramların kullanım sıklıkları tablolaştırılmıştır.

Tablo 2. Garantör Devletler Kategorisi

\begin{tabular}{|l|c|c|c|c|l|}
\hline \multicolumn{1}{|c|}{} & 16.07 .1974 & 17.07 .1974 & 18.07 .1974 & 19.07 .1974 & \\
\hline \multirow{5}{*}{ Garantör Devlet } & - & 4 & - & - & Cumhuriyet \\
\cline { 2 - 7 } & - & 2 & 3 & 2 & Milliyet \\
\cline { 2 - 7 } & - & - & - & - & Hürriyet \\
\cline { 2 - 7 } & - & 1 & - & - & Milli Gazete \\
\hline \multirow{5}{*}{ Türkiye } & 4 & 12 & 3 & 10 & Cumhuriyet \\
\cline { 2 - 7 } & 13 & 4 & 6 & 7 & Milliyet \\
\cline { 2 - 7 } & 6 & 2 & 5 & 5 & Hürriyet \\
\cline { 2 - 7 } & - & 6 & 1 & - & Milli Gazete \\
\hline Yunanistan & 9 & 24 & 10 & 16 & Cumhuriyet \\
\hline
\end{tabular}




\begin{tabular}{|c|c|c|c|c|l|}
\hline \multirow{5}{*}{} & 16 & 20 & 13 & 8 & Milliyet \\
\cline { 2 - 6 } & 8 & 11 & 13 & 10 & Hürriyet \\
\cline { 2 - 6 } & 1 & 4 & 2 & 5 & Milli Gazete \\
\hline \multirow{3}{*}{ İngiltere } & 9 & 19 & 7 & 10 & Cumhuriyet \\
\cline { 2 - 6 } & 3 & 9 & 10 & 10 & Milliyet \\
\cline { 2 - 6 } & 8 & 11 & 13 & 10 & Hürriyet \\
\cline { 2 - 6 } & 1 & 4 & 2 & 5 & Milli Gazete \\
\hline
\end{tabular}

Tablo analiz edildiğinde ilk dikkat çeken nokta, garantör devletlerin sıklıkla haberlerde anıldığıdır. Dört günlük gazetelerin birinci sayfalarında Türkiye 84 defa ifade edilirken, Yunanistan 170, İngiltere 131 defa ifade edilmiştir. Garantör Devlet kavramı ise 12 defa kullanılmıştır. Anılma sayılarını dikkate aldığımızda en fazla Yunanistan'ın anıldığı görülmektedir. Yunanistan'ın ardından İngiltere'nin de çok sık anıldığı anlaşılmaktadır. Fakat haber metinlerinin anlamları dikkate alındığında Yunanistan ile İngiltere arasında ciddi bir farkın olduğu anlaşılmaktadır. Yunanistan'ın anıldığı haberlerin içerikleri olumsuzdur ve Yunanistan, Kıbrıs olaylarının sorumlusu olarak görülmektedir. İngiltere ise Türkiye ile Yunanistan arasında bir denge mekanizması görevindedir. Adanın son hak sahibi olması ve o dönemin en büyük devletlerinden birisi olmas1, Türkiye'nin İngiltere ile ortak müdahale isteğini sıklıkla dile getirmesini sağlamıştır. Haberlerde de ortak müdahale düşüncesi sürekli ifade edilmiştir. Ecevit'in Kıbrıs'ta yaşananları Wilson ile konuşmak için Londra'ya gitmesi zaten İngiltere'nin oldukça önemli bir noktada olduğunu göstermektedir. Haberlerde de sıklıkla anılması İngiltere'nin bu önemli konumuna uygun bir durumdur. İngiltere'nin adının en sık anıldığı gazete ise Cumhuriyet Gazetesi'dir. Cumhuriyet Gazetesi'nde İngiltere ismi 45 defa geçmiştir. $\mathrm{Bu}$ kadar sık kullanım tesadüf değildir. Cumhuriyet Gazetesi'nin 37. Hükümet ortaklarından CHP'ye yakınlığı bilinmektedir. Ecevit'in Londra seyahatinin de çok geniş yer aldığ 1 gazetede İngiltere kavramının bu kadar sık anılması normaldir. Fakat Milli Gazetede sadece 12 defa İngiltere'nin adının anılması daha dikkat çekicidir. Hükümetin diğer ortağı olan MSP'ye yakınlığı ile bilinen Milli Gazete'nin bu tutumu Ecevit'in Londra seyahatinin fazla ön planda olmasını engelleme düşüncesi ya da hükümet ortaklarından MSP'nin ortak müdahaleye karş1 olduğu şeklinde değerlendirilebilir.

Tablo 3. Diğer Devletler Kategorisi

\begin{tabular}{|c|c|c|c|c|l|}
\hline & 16.07 .1974 & 17.07 .1974 & 18.07 .1974 & 19.07 .1974 & \\
\hline \multirow{5}{*}{ ABD } & 5 & 2 & 1 & 16 & Cumhuriyet \\
\cline { 2 - 7 } & 1 & 7 & 6 & 7 & Milliyet \\
\cline { 2 - 7 } & 7 & 7 & 4 & 8 & Hürriyet \\
\cline { 2 - 7 } & - & 1 & 3 & 2 & Milli Gazete \\
\hline \multirow{5}{*}{ Sovyetler Birliği / Rusya } & - & 1 & - & 2 & Cumhuriyet \\
\cline { 2 - 7 } & 3 & 7 & 3 & 3 & Milliyet \\
\cline { 2 - 7 } & - & 8 & 4 & 2 & Hürriyet \\
\cline { 2 - 7 } & - & - & - & 1 & Milli Gazete \\
\hline
\end{tabular}

İncelenen gazetelerde ABD 77, Rusya (Sovyetler Birliği) 34 defa anılmıştır ${ }^{4}$. Kıbrıs Darbesi ve Kıbrıs Barış Harekâtı dönemi; dünyanın iki kutuplu olduğu, 'Soğuk Savaş' diye ifade

\footnotetext{
4 Gazetelerde, Mısır, Pakistan, İsveç, Fransa, İtalya gibi birçok devlet, haberlerin içinde anılmıştır fakat anlamlı bir tekrarı olmadığı, spesifik haberlerin içinde geçtiği için tabloya dahil edilmemiştir.
} 
edilen bir dönemdir ${ }^{5}$. Dünyanın Batı Bloku ve Doğu Bloku olarak ayrıştığı bu dönemin iki güç merkezi olan ABD ve SSCB (Aşkan ve Üzümcü, 2020, s. 71-92) Kıbrıs haberlerinde sıklıkla yer almıştır. Türkiye, İngiltere ve Yunanistan Batı Bloku ülkeler içinde anılan ülkelerdir ${ }^{6}$. Bu nedenle ABD'nin haberlerde daha sık anılması bir sürpriz değildir. Buna rağmen SSCB de azımsanmayacak sıklıkta haberlerde yer almıştır. Özellikle Makarios'un SSCB'ye yakınlığı tüm dünya tarafından bilinmekteydi (Qasıml1, 2013, s. 68). Zaten darbeden kısa bir süre önce Makarios'un Çin'e yaptığı ziyaret bu yakınlığın açık bir delili olarak kabul edilebilir. ${ }^{7} \mathrm{Bu}$ yakınlık Kıbrıs'ın dünya siyasetinde daha dikkate değer bir noktaya ulaşmasının en önemli nedenlerinden birisidir. SSCB'ye yaklaşan Makarios'a karşı ABD'nin politikaları değişmiştir. ABD, Akdeniz'de komünizm istemediği için Makarios'a karşı girişilen eylemleri desteklediği iddiaları sıklıkla ifade edilmiştir. Hatta ABD’nin darbeyi kınamaması darbe girişiminin ardında ABD mi var? sorusunun sorulmasına da neden olmuştur. Kısaca Akdeniz'de Komünizm istemeyen ABD, Makarios'a da sıcak bakmamaktadır. SSCB ise Makarios'u koruma ve Kıbrıs'1 Doğu Blokuna alamasa bile Batı Bloku ülkelerden olmasını önleme çabası içindedir (Günal, 2019, s. 2168-2207). Bu durum haberlerde iki ülkenin de sıklıkla anılmasını sağlamıştır.

Tablo 4. Uluslararası Kuruluşlar Kategorisi

\begin{tabular}{|l|c|c|c|c|l|}
\hline & 16.07 .1974 & 17.07 .1974 & 18.07 .1974 & 19.07 .1974 & \\
\hline \multirow{3}{*}{ BM $^{8}$} & 2 & 4 & 2 & 7 & Cumhuriyet \\
\cline { 2 - 7 } & 2 & 6 & - & 6 & Milliyet \\
\cline { 2 - 7 } & 1 & 2 & - & 1 & Hürriyet \\
\cline { 2 - 7 } & - & - & - & 2 & Milli Gazete \\
\hline \multirow{5}{*}{ NATO $^{9}$} & 5 & 5 & 7 & 2 & Cumhuriyet \\
\cline { 2 - 7 } & 5 & 1 & 6 & 1 & Milliyet \\
\cline { 2 - 7 } & - & - & 10 & 2 & Hürriyet \\
\cline { 2 - 7 } & 1 & 2 & 4 & 2 & Milli Gazete \\
\hline
\end{tabular}

BM ve NATO’nun da haberlerde sıklıkla anıldığı görülmektedir. Özellikle NATO’nun bu kadar sık anılmasını Türkiye ile Yunanistan'ın her ikisinin de NATO üyesi olması ile bağdaştırabiliriz. NATO olası saldırılara karşı birlikte savunma mantığını taşımaktadır (www.nato.int, 2020). Böyle bir kuruluşa üye iki ülkenin birbirleri ile sorun yaşaması veya savaşması NATO'nun dağılmasına neden olabilecek bir kriz oluşturabilecek büyüklüktedir. Soğuk Savaş gibi bir dönemde NATO'nun Batı Bloku için anlamı oldukça önemlidir (Kasım, 2007, s. 59). Bu nedenle NATO'nun dağılma ihtimali üye devletleri tedirgin etmektedir. Bu çekinme NATO'nun Kıbrıs sürecindeki haberlerde sıklıkla kullanılmasını sağlamıştır. NATO toplamda 53 defa gazetelerde anılmışken BM ise 35 defa anılmıştır.

\footnotetext{
${ }^{5}$ II. Dünya Savaşı'nı kazanan devletlerden ABD ve SSCB'nin anlaşmazlıkları ve çatışmalarını silah kullanmadan sürdürdükleri tarihsel döneme Soğuk Savaş Dönemi denilmektedir (Sander, 2014, s. 224).

${ }^{6}$ Soğuk Savaş sırasında Sovyetler Birliği ve müttefiklerine karşı ABD ve NATO ile ittifak olan ülkeler Batı Bloku olarak ifade edilir (www.wikipedia.org, 2020).

${ }^{7}$ Makarios'un Pekin ziyaretlerini konu edinen haberler Türkiye'deki gazetelerde de yayınlamıştır (22.04.1974, 16.05.1974 Milliyet, 23.04.1974 Milli Gazete, 23.04.1974 Cumhuriyet).

${ }^{8}$ Birleşmiş Milletler, uluslararası barış ve güvenlik için birlikte çalışmak, dostane ilişkiler geliştirmek, sosyal ilerlemeyi, daha iyi yaşam standartlarını ve insan haklarını desteklemek ve geliştirmek amacıyla 193 ülkeyi bir araya getiren uluslararası bir örgüttür. Günümüzde BM, 4 kıtada 120.000 barış gücü askeri konuşlandırmaktadır (www.europa.eu, 2020).

${ }^{9}$ Kuzey Atlantik Antlaşması Örgütü bugün dünyadaki en önemli uluslararası kuruluşlardan biridir. Politik ve askeri bir ittifak olan bu örgüt Avrupa ve Kuzey Amerika'dan 30 ülkeyi bir araya getirir. Bu ülkeler bir araya gelerek güvenlik ve savunma konuları üzerinde danışmalarda bulunurlar ve işbirliği yaparlar. NATO, tartışmalar ve ortaklıkları vasıtasıyla üye ülkelerinin topraklarında veya bu toprakların dışında çatışmaların önlenmesine katkıda bulunur (www.nato.int, 2020).
} 
Tablo 5. Türk Yöneticiler Kategorisi

\begin{tabular}{|c|c|c|c|c|c|}
\hline & 16.07 .1974 & 17.07.1974 & 18.07 .1974 & 19.07.1974 & \\
\hline \multirow{4}{*}{ Bülent Ecevit } & 4 & 8 & 13 & 16 & Cumhuriyet \\
\hline & 7 & 3 & 10 & 12 & Milliyet \\
\hline & 5 & 3 & 3 & 9 & Hürriyet \\
\hline & 3 & 5 & - & 7 & Milli Gazete \\
\hline \multirow{4}{*}{ Necmettin Erbakan } & - & - & - & - & Cumhuriyet \\
\hline & - & - & 2 & 1 & Milliyet \\
\hline & - & - & - & 1 & Hürriyet \\
\hline & - & - & 4 & 2 & Milli Gazete \\
\hline \multirow{4}{*}{ Semih Sancar } & 4 & 1 & - & - & Cumhuriyet \\
\hline & 2 & - & - & - & Milliyet \\
\hline & 4 & - & - & - & Hürriyet \\
\hline & - & - & - & - & Milli Gazete \\
\hline \multirow{4}{*}{ Hasan Esat Iş1k } & - & 3 & - & - & Cumhuriyet \\
\hline & - & 2 & 1 & - & Milliyet \\
\hline & - & - & - & - & Hürriyet \\
\hline & - & - & - & - & Milli Gazete \\
\hline \multirow{4}{*}{ Fahri Korutürk } & - & 4 & 3 & - & Cumhuriyet \\
\hline & 1 & 3 & - & 2 & Milliyet \\
\hline & - & 2 & 1 & 1 & Hürriyet \\
\hline & 2 & 3 & 2 & 1 & Milli Gazete \\
\hline \multirow{4}{*}{ Turan Güneş } & - & - & - & - & Cumhuriyet \\
\hline & 3 & - & - & - & Milliyet \\
\hline & - & - & - & - & Hürriyet \\
\hline & - & - & - & - & Milli Gazete \\
\hline \multirow{4}{*}{ Rauf Denktaş } & 1 & - & - & - & Cumhuriyet \\
\hline & - & - & - & - & Milliyet \\
\hline & - & - & - & - & Hürriyet \\
\hline & 1 & - & - & - & Milli Gazete \\
\hline
\end{tabular}

İncelenen haberlerde en sık anılan Türk yöneticinin dönemin Başbakan'1 Bülent Ecevit (108) olduğu görülmektedir. Ecevit'ın bu kadar sık anılması Türkiye için sürecin açık ara tek lideri olduğunu göstermektedir. Ecevit' in ardından Korutürk toplamda 25 defa anılmıştır. Korutürk'ün de isminin yoğun geçmesi devletin en üst kademesi olan Cumhurbaşkanlığının da Kıbrıs konusunda etkin olduğunu, Türkiye'nin en üst makamdan konuyu değerlendirdiğini göstermektedir. Fakat Erbakan'ın (10) adının çok az geçmesi hükümet ortaklarından MSP'nin süreçte pek etkin olmadığı anlamını taşımaktadır. Kıbrıs Harekâtından sonra Mücahit ismi ile anılan Erbakan'ın bu süreçte daha aktif olması gerektiği düşünülebilir. Darbe olayının gerçekleştiği dönemde Dışişleri Bakanı olan Turan Güneş'in (3) Pekin'de resmi ziyarette olması süreçte isminin az anılmasına sebep olmuş, Güneş yerine Milli Savunma Bakanı Hasan Esat Işık ${ }^{10}$ 'n (6) daha sık anılmasına neden olmuştur. Dönemin Genelkurmay Başkanı Semih Sancar ise 11 defa anılmıştır. Sancar'ın böyle bir olağanüstü durumda daha sık anılacağı düşünülse de politikacılardan daha az anılması Türkiye'nin savaş değil barış politikası ile örtüşen bir durumdur. Türkiye tüm harekât süresince savaşa değil sulha vurgu yapmış ve diplomatik yolları sonuna kadar denedikten sonra harekâta karar vermiştir. Sancar'ın adının gazete haberlerinde az

\footnotetext{
${ }^{10}$ Işık, Milli Savunma Bakanlığı beraberinde Dışişleri Bakanlığı vekilidir (Yayla, 2014, s. 91).
} 
anılmasının temel nedeni de bu durumdur. Tablonun en dikkat çekici yönü ise Denktaş'ın sadece 2 defa ismi ile karşılaşılmış olunmasıdır. Denktaş hem Kıbrıs Devleti Cumhurbaşkanı Yardımcısı hem de Türk Toplum Temsilcisi'dir. Buna rağmen Kıbrıs haberlerinde çok az yer almıştır. Bu durum da Kıbrıs konusunun artık Denktaş’ı yani Kıbrıs Türklerini aştığını, Garantör devlet olma sıfatı ile Türkiye'nin konuya el attığını göstermektedir.

Tablo 6. Yabancı Yöneticiler Kategorisi

\begin{tabular}{|c|c|c|c|c|c|}
\hline & 16.07.1974 & 17.07.1974 & 18.07 .1974 & 19.07 .1974 & \\
\hline \multirow{4}{*}{ Joseph John Sisco ${ }^{11}$} & - & - & - & 6 & Cumhuriyet \\
\hline & - & - & 1 & 3 & Milliyet \\
\hline & - & - & 1 & 6 & Hürriyet \\
\hline & - & - & - & 3 & Milli Gazete \\
\hline \multirow{4}{*}{ Henry Kissinger $^{12}$} & - & - & - & - & Cumhuriyet \\
\hline & 1 & 1 & 4 & 1 & Milliyet \\
\hline & - & - & - & 1 & Hürriyet \\
\hline & - & - & - & - & Milli Gazete \\
\hline \multirow{4}{*}{ Harold Wilson ${ }^{13}$} & - & 1 & 4 & 3 & Cumhuriyet \\
\hline & - & - & 8 & - & Milliyet \\
\hline & - & - & 2 & 2 & Hürriyet \\
\hline & - & - & - & 5 & Milli Gazete \\
\hline \multirow{4}{*}{ Kurt Waldheim ${ }^{14}$} & - & 3 & 1 & - & Cumhuriyet \\
\hline & 2 & 3 & - & - & Milliyet \\
\hline & - & 1 & - & - & Hürriyet \\
\hline & - & - & - & - & Milli Gazete \\
\hline \multirow{4}{*}{ Joseph Luns ${ }^{15}$} & - & 2 & 2 & - & Cumhuriyet \\
\hline & - & - & - & - & Milliyet \\
\hline & - & - & 1 & - & Hürriyet \\
\hline & - & - & - & - & Milli Gazete \\
\hline \multirow{4}{*}{ James Callaghan $^{16}$} & - & 2 & 1 & - & Cumhuriyet \\
\hline & 1 & 1 & - & - & Milliyet \\
\hline & - & - & - & - & Hürriyet \\
\hline & - & - & - & - & Milli Gazete \\
\hline \multirow{4}{*}{ Richard Nixon ${ }^{17}$} & - & - & - & 3 & Cumhuriyet \\
\hline & - & - & 2 & - & Milliyet \\
\hline & - & - & 1 & - & Hürriyet \\
\hline & - & - & - & 1 & Milli Gazete \\
\hline
\end{tabular}

11 Sisco,1951'den 1976'ya kadar ABD Dışişleri Bakanlığı'nda Yakın Doğu ve Güney Asya'dan sorumlu Dışişleri Bakan Yardımcısı (1969-74) ve Siyasi İşler Müsteşarı (1974-76) dâhil olmak üzere birçok görevde bulunmuştur (www.b.org, 2020).

12 Kissinger, 1973-1977 arası ABD Dışişleri bakanı ve Ulusal güvenlik danışmanlığı görevlerinde bulunmuş Nobel ödüllü siyasetçidir (www.biyografi.info, 2020)

${ }^{13}$ Wilson, 1974-76 yılları arasında İngiltere Başbakanı (www.bbc.com, 2020).

${ }^{14}$ Avusturyalı diplomat ve siyaset adamıdır. 22 Aralık 1971'de BM Genel Sekreterliğine getirildi ve 1982'ye kadar devam etti (https://www.dersimiz.com, 2020).

${ }^{15}$ Hollandalı siyasetçidir. 1971-1984 arasında NATO’nun 5. Genel Sekreteri olarak görev yapmıştır (http://kimdirkimdir.com, 2020).

${ }^{16} 1974$ yılında İngiltere Wilson hükümetinin Dışişleri bakanıdır (www.hurriyet.com.tr, 2020).

${ }^{17}$ 1969-1974 yılları arasında ABD Başkanıdır (https://www.bilgiustam.com, 2020). 
Kıbrıs ya da Türkiye'de yönetici olmayan fakat Kıbrıs haberlerinde adları en çok anılan kişileri incelediğimizde en fazla anılan kişinin İngiltere Başbakanı Wilson (25) olduğu görülmektedir. Wilson'un s1k anılmasının sebebi İngiltere'nin sık anılmasının sebepleri ile paraleldir. Wilson ile İngiltere Dışişleri Bakanı Callaghan (5) da haberlerde yer almıştır. ABD’li yöneticilerden Nixon (7), Kissinger (8) ve Sisco (20) da yoğun bir şekilde haberlerde geçmiştir. Nixon, Kissinger ve Sisco'nun isimlerinin bu kadar yoğun (toplam 35) anılması ABD'nin Kıbrıs konusuna verdiği önemi ve ilgiyi göstermektedir. ABD Kıbrıs konusunda birçok süreçte aktif rol almış, bazı anlarda ise Ecevit'in tepkileri ile süreçten soyutlanmaya çalışılmıştır. Ecevit'in ABD'yi süreç dışında tutma isteğinin temel nedeni ABD'nin Garantör Devletlerden birisi olmaması ve ayrıca ABD'nin darbecilere karşı net bir tepki koymamasıdır. BM Genel Sekreteri Waldheim (10) ile NATO Genel Sekreteri Luns'un da (5) isimlerinin anılması uluslararası kuruluşların süreci yakından takip ettiklerinin önemli bir delilidir.

Tablo 7. Örgütler Kategorisi

\begin{tabular}{|l|c|c|c|c|l|}
\hline \multirow{5}{*}{ CUNTA } & 16.07 .1974 & 17.07 .1974 & 18.07 .1974 & 19.07 .1974 & \\
\cline { 2 - 7 } & - & 10 & 3 & 4 & Cumhuriyet \\
\cline { 2 - 7 } & - & - & - & - & Milliyet \\
\cline { 2 - 7 } & - & 2 & - & - & Hürriyet \\
\hline \multirow{5}{*}{ ENOSIS } & 2 & - & - & 2 & Milli Gazete \\
\cline { 2 - 7 } & 3 & 1 & - & - & Milliyet \\
\cline { 2 - 7 } & 1 & - & - & - & Hürriyet \\
\hline & - & - & - & 1 & Milli Gazete \\
\hline \multirow{5}{*}{ EOKA } & 1 & 4 & - & - & Cumhuriyet \\
\cline { 2 - 7 } & 4 & 1 & - & - & Milliyet \\
\cline { 2 - 7 } & 3 & 2 & - & - & Hürriyet \\
\cline { 2 - 7 } & - & - & - & - & Milli Gazete \\
\hline
\end{tabular}

Gazeteler analiz edildiğinde Yunan hükümeti için "Cunta” (22) kavramının sıklıkla kullanıldığı görülmüş̧ür. Olayların yaşandığı dönemde (1967-1974) Yunanistan'da demokratik yollarla seçilmiş iktidar darbe ile yıkılmış yerine askeri yönetim gelmiştir (Kılıçoğlu, 2010, s. 141-143). Gazeteler sıklıkla bu duruma vurgu yapmış ve Yunanistan'daki antidemokratik yönetimin Kıbrıs'ı da aynı yöntemle demokrasiden uzaklaştırmak istediklerini yazmıştır. Özellikle iktidara yakınlığı ile bilinen Cumhuriyet Gazetesi "Cunta" vurgusunu oldukça sık kullanmıştır. Kıbrıs ile ilgili yazılmış tüm kaynaklarda üzerinde uzunca durulan ENOSİS (11) düşüncesi ve EOKA (15) örgütü de gazetelerin ifade ettikleri kavramlar arasındadır. Darbecilerin amaçlarının ENOSİS'e ulaşmak olduğunu yazan gazeteler, darbecilerin de EOKA örgütü ile aynı doğrultuda olduğunu belirtmiştir. Sampson'un Cumhurbaşkanı ilanı da bu düşüncenin doğruluğunu güçlendirmektedir. Çünkü Sampson EOKA örgütüne üye olmaktan ve çeşitli cinayetlerden suçlanmış, hatta gazetedeki köşesinde bazı cinayetleri alenen yazdığı da bilinmektedir. 
Tablo 8. Aktarım Yöntemleri Kategorisi

\begin{tabular}{|c|c|c|c|c|c|}
\hline & 16.07.1974 & 17.07.1974 & 18.07.1974 & 19.07.1974 & \\
\hline \multirow{4}{*}{ Kıbrıs Olayları } & - & - & - & - & Cumhuriyet \\
\hline & - & - & - & - & Milliyet \\
\hline & - & - & - & - & Hürriyet \\
\hline & - & - & - & 5 & Milli Gazete \\
\hline \multirow{4}{*}{ Milli Dava } & - & - & - & 1 & Cumhuriyet \\
\hline & - & - & - & - & Milliyet \\
\hline & - & - & - & - & Hürriyet \\
\hline & - & - & - & - & Milli Gazete \\
\hline \multirow{4}{*}{ Kıbrıs Olayları } & - & - & - & - & Cumhuriyet \\
\hline & - & - & - & - & Milliyet \\
\hline & - & - & - & - & Hürriyet \\
\hline & - & - & - & - & Milli Gazete \\
\hline \multirow{4}{*}{ Kibris Sorunu } & 1 & 1 & 1 & 1 & Cumhuriyet \\
\hline & - & - & 1 & - & Milliyet \\
\hline & - & - & - & - & Hürriyet \\
\hline & - & 1 & - & - & Milli Gazete \\
\hline \multirow{4}{*}{ Kıbrıs Meselesi } & 1 & - & - & - & Cumhuriyet \\
\hline & - & - & - & - & Milliyet \\
\hline & - & - & - & - & Hürriyet \\
\hline & - & - & 2 & - & Milli Gazete \\
\hline
\end{tabular}

Gazeteler incelendiğinde Kıbrıs'ta yaşanan durumu ifade ediş şekillerinin de değişiklik gösterdiği gözlemlenmiştir. Fakat büyük bir oranda Kıbrıs'ta yaşananlar ifade edilirken "Kıbrıs Sorunu" (6) kullanılmıştır. "Kıbrıs Meselesi” (3) ve "Milli Dava” (1) gibi daha çok Türk bakış açısına uygun ifadelerin ise daha az kullanıldığı, nispeten daha tarafsız bir bakışla "Kıbrıs Sorunu" (6) ifadesinin milli bakış açısından daha fazla kullanıldığı tespit edilmiştir. Kıbrıs gibi Türkiye ve Türk Milleti için önemli bir konun ifade edilişinde en sık kullanılan kavramın "sorun" kavramı olması gazetelerin Kıbrıs'ın önemini azaltıp sorun oluşturan yer imajı oluşmasına neden olacağı gibi Kıbrıs'ın “yavruvatan” kimliği ile de örtüşmemektedir. 
Tablo 9. Kategori Dışı Sık Anılan Kavramlar ${ }^{18}$

\begin{tabular}{|c|c|c|c|c|c|}
\hline & 16.07 .1974 & 17.07.1974 & 18.07.1974 & 19.07.1974 & \\
\hline \multirow{4}{*}{ Oldu Biti } & 1 & - & - & - & Cumhuriyet \\
\hline & 1 & - & - & - & Milliyet \\
\hline & - & 1 & - & - & Hürriyet \\
\hline & - & - & - & - & Milli Gazete \\
\hline \multirow{4}{*}{ Ortak Müdahale } & - & 1 & - & - & Cumhuriyet \\
\hline & - & 2 & 3 & - & Milliyet \\
\hline & - & 1 & - & - & Hürriyet \\
\hline & - & 1 & - & - & Milli Gazete \\
\hline \multirow{4}{*}{ Birlik Beraberlik } & - & 2 & - & 1 & Cumhuriyet \\
\hline & - & - & - & - & Milliyet \\
\hline & - & - & - & - & Hürriyet \\
\hline & - & - & 2 & - & Milli Gazete \\
\hline \multirow{4}{*}{ Türk-Yunan İlişkileri } & 2 & 1 & - & 3 & Cumhuriyet \\
\hline & 2 & - & - & - & Milliyet \\
\hline & - & - & 4 & - & Hürriyet \\
\hline & - & 2 & - & - & Milli Gazete \\
\hline \multirow{4}{*}{ Yunanlı Subaylar } & 3 & 7 & 9 & 6 & Cumhuriyet \\
\hline & 13 & 2 & 5 & 3 & Milliyet \\
\hline & 4 & 3 & 5 & 7 & Hürriyet \\
\hline & 5 & - & 3 & - & Milli Gazete \\
\hline \multirow{4}{*}{ TBMM } & 2 & 5 & 5 & 4 & Cumhuriyet \\
\hline & - & 4 & - & 3 & Milliyet \\
\hline & - & 2 & 3 & 3 & Hürriyet \\
\hline & - & 3 & 3 & 7 & Milli Gazete \\
\hline
\end{tabular}

Gazeteler incelendiğinde göze çarpan diğer bazı kavramlar yukarıdaki tabloda aktarılmıştır. İlk dikkat çeken kavramlardan biri "Oldubitti” (3) kavramıdır. Yunanistan'ın amacını izah etmek için kullanılan bu kavram Türk siyasetçiler tarafından kullanılmış ve Türkiye'nin oldubittiyi kabul etmeyeceği ifade edilmiştir. Ecevit'in Londra'da Wilson ile görüşme haberlerinde en çok vurgulanan kavram ise "Ortak Müdahale" (8) kavramıdır. Türkiye Kıbrıs'a tek başına müdahale etmektense Garantör Devlet olduğu için İngiltere ile birlikte hareket etmek istemiştir. $\mathrm{Bu}$ nedenle Ecevit sıklıkla ortak müdahale üzerinde durmuştur. Ecevit'in ortak müdahale istemesindeki temel amaçlardan ilki Türkiye'nin Kıbrıs'1 kendi himayesine almaya çalışmadığını göstermek, ikincisi ise ittifak kurarak gelecek uluslararası tepkileri azaltmak olarak değerlendirilebilir. Gazetelerin TBMM ile ilgili yaptıkları haberlerin içinde sıklıkla kullanılan önemli kavramlardan birisi "Birlik Beraberlik" (5) kavramıdır. TBMM'de bulunan tüm siyasi partiler Kıbrıs konusunda hemfikir olmuş ve ortak karar almıştır. $\mathrm{Bu}$ durum Türkiye'nin Kıbrıs konusunda ne kadar hassas olduğunu göstermektedir. Kıbris konusu bu birlik duruşu ile "milli dava" statüsüne yükselmiştir. Meclisteki bu birlik tabanda da birliğin olduğunu göstermekte ve Türk halkının tamamının Kıbrıs ile ilgili ortak duygu ve düşüncede olduğunu aktarmaktadır. Kıbrıs konusu Türkiye için hep bir barış politikası ile birlikte yürütülmüştür.

\footnotetext{
${ }^{18} \mathrm{Bu}$ tablodaki veriler, kategorilerde yer almayan fakat eleştirel jeopolitik yorumlama için yol gösterici nitelikte olan verilerdir. $\mathrm{Bu}$ ifadelerin anılma sıklıkları metinlerin tahayyül, temsil ve kimlik inşalarını hangi bağlamlarda oluşturduklarını ifade etmek için kullanılacaktır.
} 
Gazetelerde en s1k kullanılan kavramlardan birisi de "Yunanlı Subaylar" (75) ifadesidir. Türkiye darbenin olduğu günden beri yaşananlarda Kıbrıs'taki Yunanlı askerleri suçlamış, Yunanistan'ın bu askerler aracılığı ile darbeyi gerçekleştirdiğini ifade etmiştir. Bu düşünce gazetelerde de sıklıkla yer almış ve Türkiye'nin düşüncesi kamuoyuna açıkça ifade edilmiştir. Yunanlı Subaylar kavramının sık kullanılması hem şartlar hem yaşananlar hem de Türkiye'nin düşüncesi ile uyuşan bir durumdur.

Çok sık kullanılan bir diğer kavram da TBMM (44) kavramıdır. Bu kavramın sık kullanılması Türkiye'nin demokratik bir ülke olduğunu kararların öncelikle mecliste tartışıldığını göstermektedir. Ayrıca birlik ve beraberlik kavramı ile ele alındığında meclisin Kıbrıs konusunda yapılan tüm girişimleri ortak kararlarla yaptıkları anlaşılmaktadır.

Gazetelerin üzerinde durdukları ve çalışmada ele alınan son kavram ise "Türk-Yunan İlişkileri" (14) kavramıdır. İki NATO ülkesinin sorun yaşaması ve birbirleriyle savaşması Batı Bloku ülkelerin en fazla çekindikleri sonuçtur. $\mathrm{Bu}$ durum gazetelere de yansımıştır. Türk gazeteler Türk-Yunan ilişkisinin üzerinde sıklıkla durmuş olası ihtimalleri hesaplamıştır. Balkan Savaşlarından beri bir çekişme içinde olan iki ülkenin ilişkileri 1974 yılında da pek olumlu değildir. Kıbrıs'ta yaşanan bu durum ilişkilerin daha da gerilmesine neden olmuş ve kanlı bir sonucun ortaya çıkması tüm kesimleri tedirgin etmiştir. Gazetelerde 'Yunan ordusu Trakya'ya asker yı̆̆dı, donanması denize açıldı' gibi haberler yer almış ve bu haberlerde olası sonuçların nasıl olacağı tartışılmıştır. Ayrıca Türk-Yunan ilişkisi gazetelerde, savaş, kargaşa ve gerilim ifadeleri ile kullanılmıştır ve bu durumda zihinlerde olumsuz etkiler bırakmaktadır.

\section{Sonuç ve Tartışma}

15 Temmuz 1974 tarihinde gerçekleşen Makarios’a yönelik darbenin ardından 20 Temmuz 1974'de Türkiye Kıbrıs'a “Kıbrıs Barış Harekâtı” isimli bir askeri harekât düzenlemiştir. Bu çalışmada, darbe ile harekât günleri arasında kalan 16,17,18 ve 19 Temmuz 1974 tarihli Milliyet, Hürriyet, Cumhuriyet ve Milli Gazete incelenerek gazetelerin birinci sayfalarındaki Kıbrıs ile ilgili haberler değerlendirilmiştir. Belirtilen tarih aralığında incelenen dört gazetenin tüm sayfalarında toplam 300'den fazla Kıbrıs ile ilgili haber yayınlanmıştır. Gazetelerin birinci sayfalarında ise Kıbrıs dışında çok az habere yer verilmiş, ayrıca bu süre içinde gazetelerin Kıbrıs konusu dışında hiç manşetle çıkmadığı da görülmüştür. Bu veriler bize Türk basının Kıbrıs’ta yaşanan olayları oldukça önemsediğini göstermektedir.

Gazetelerde, Yunanistan ve İngiltere devletlerinin isimlerinin oldukça sık anıldı ̆̆ görülmektedir. Haberlerin bağlamları kapsam dışı bırakılıp sadece anılma sıklıkları ile bakıldığında, Kıbrıs'ta yaşanan bu gelişmelerin sorumluları ile ilgili ipuçları göze çarpmaktadır. Fakat haberler metinleri ile birlikte değerlendirildiğinde Yunanistan ve İngiltere'nin s1k anılmasının sebeplerinin farklı olduğu anlaşılmaktadır. Yunanistan'ın darbe eylemini gerçekleştirenlerin destekçisi olarak görüldüğü ve bu nedenle sıkça telaffuz edildiği görülürken, İngiltere'nin ise garantör devlet olması, Türkiye'nin İngiltere'yi sürece müdahil etme isteği ve Londra görüşmeleri nedeniyle sık anıldığı anlaşılmaktadır. Bu durum bizi eleştirel jeopolitik bir sonuca götürmektedir. Sık anıldığı görülen iki devlet ile ilgili bir kimlik inşası mevcuttur. Bu iki devletin kimlik inşası üzerinden ise Türkiye'nin kimlik inşasının yapıldığı anlaşılmaktadır. Yunanistan, Türkiye ve İngiltere ile birlikte Garanti Antlaşması'nı imzalayarak Kıbrıs Devleti'nin hamisi statüsünü kazanmıştır. Görev ve sorumlulukları Kıbrıs'ı korumak ve kollamak olan Yunanistan'ın Kıbrıs'ta demokratik yöntemlerle seçilmiş Cumhurbaşkanı Makarios'un devrilmesine destek vermesi Yunanistan'ın "hami-koruyucu” kimliğini yıkmıştır. Türk gazeteleri bu durumu neredeyse her haber metni içinde ifade ederek Yunanistan'ın artık Garantör Devlet olamayacağını hem iç hem de uluslararası kamuoyuna deklare etmiştir. Yıkılan bu kimlik yerine ise darbeyi gerçekleştirenlerin Yunan Cunta yönetimine bağlı subaylar olması gerekçesi ile "işgalci”" kimliği inşa edilmiş ve yine iç ve diş kamuoyuna duyurulmuştur. 
Benzer bir kimlik değişimi İngiltere için de geçerlidir. İngiltere adanın son hak sahibi ve Garantör Devletlerden birisidir. Fakat İngiltere Yunanistan'ın yaptığı bu darbeye karşı Kıbrıslı Türk ve Rum halkı koruma girişiminde bulunmaması, İngiltere'nin de Garantör Devlet kimliğini zedelemiştir. Bu iki kimlik değişimi Türkiye'nin de kimliğinin değişmesini sağlamıştır. $\mathrm{O}$ güne kadar Garantör Devlet olma sebebinin adadaki Türk nüfusun hamiliğini gerçekleştirmek olduğu düşünülen Türkiye'nin, Kıbrıs'ın işgal edilmesini önleme çabaları önemli bir değişim gerçekleştirmiştir. Türkiye sadece Türkleri değil, Rumları da koruma ve kollama isteğini açıkça göstermiştir. Böylece Türkiye artık adanın tamamın hamisi statüsüne yükseltmiştir.

Son bir kimlik değişikliği ise Rum toplumu kimliği ile ilgilidir. Haber metinlerindeki çatışma ve saldırı ifadeleri Rumların zor durumda olduğunu ve mağdur edildiğini göstermektedir. Yıllarca Kıbrıs Türklerini adadan kaçırmak için çaba sarf eden ve her firsatta Türklere yönelik kanlı eylemler gerçekleștiren Rumların saldırıya uğrayan taraf olması ve darbe olaylarında yoğun çatışmalarla öldürülmeleri o güne kadar gelen "cani Rum” kimliğini de değiştirmiş ve "mağdur" Rum kimliği inşa edilmiştir. Rum kimliğindeki değişimin en önemli sonucu Türk kimliğinin inşasını güçlendirmesidir. Rumlar üzerinden kurulan Türk kimliği ise koruyan, kollayan, merhamet eden ve her ne sebeple olursa olsun kimsenin zarar görmesini istemeyen Türk kimliğidir. Yani Türklerin intikam duygusuyla hareket etmediğini sulhu sağlama gayesinde olduğunu aktarmaktadır. Bu kimlik Türkiye'nin Kıbrıs Barış Harekâtını gerçekleştirirken kullandığı en önemli argümanlardan birisi olmuştur.

Kıbrıs darbesinin yaşandığı dönem dünyanın iki kutuplu olduğu bir dönemdir. Batı ve Doğu blokları arasında yaşanan soğuk savaş neredeyse tüm dünya ülkelerinde bir taraf olma ihtiyacı doğurmuş, tarafsız kalan ülkeler ise dengeleri gözetebilmek adına bazen zor kararlar vermek durumunda kalmıştır. Kıbrıs Devleti Cumhurbaşkanı Makarios dünyadaki bu kutuplaşmayı kendi çıkarları doğrultusunda kullanabilmek için SSCB ile yakınlaşmış, fakat Makarios'un bu hamlesi Batı Blokunda yer alan birçok ülkeyi rahatsız etmiştir. Çünkü ABD başta olmak üzere Batı Bloku ülkeleri Rusya'nın ve dolayısıyla komünizmin Akdeniz'e açılmasından endişe ediyorlardı. Bu durum Makarios'un Batılı ülkelerdeki sempatisinin kaybolmasına neden olmuştur. Makairos'un Batı nezdinde itibarsızlaşması Yunanistan'ın darbe eylemini planlamasını ve hayata geçirmesini de tetiklemiştir. Darbe eylemi gerçekleştikten sonra Rusya Makarios'un ve Kıbrıs'ın akıbetini sürekli sorgulamış ve Türkiye'ye ciddi bir manevi destek vermiştir. Bu destek Türkiye'nin adımlarını daha kararlı atmasını sağlarken ABD'nin darbenin ilk günlerindeki sessizliğini ve eylemsizliğini zora sokmuştur. Garantör devlet olma sıfatları ile görüşen Türkiye ve İngiltere'nin müzakerelerine ABD'de Sisco ile müdahil olmak istemiş fakat Ecevit, Garantör Devletler arasında yer almaması sebebi ile ABD'yi dışarıda tutmuştur. $\mathrm{Bu}$ verilerle haberlerdeki ABD vurgusunun çok sık olmasının sebebinin Batı Bloku ilkelerinin lideri konumu ve Türkiye ile İngiltere görüşmelerine müdahil olma arzusu olduğu anlaşılmaktadır. SSCB ya da Rusya vurgusunun ise Makarios'un son dönemlerde Doğu blokuna yakınlaşması ve dünyanın iki kutuplu halde olmasından kaynaklandığı anlaşılmaktadır. Ayrıca Kıbrıs'ta yaşanan durumun başka bir uluslararası yansıması ise Batı Blokundan oluşan NATO'nun iki üyesi Yunanistan ve Türkiye'nin, Kıbrıs konusunda karşı karşıya gelmiş ve savaşa ramak kalmış olmasıdır. Olası bir savaşın NATO'nun, belki de Batı Blokunun dağılmasına yol açabileceği gerçeği Batılı devletlerin yaşananları en az kayıpla ve hızlıca çözümleme arzusunu oluşturmuştur. Türkiye'nin oluşturduğu "kimlik" tasavvurları, Garantör devlet olma gücü ve israrla barışçıl yolları denemesi elini güçlendirirken, Yunanistan'ın tüm dünya tarafından suçlu görülmesi ise Yunanistan'a bir antipatinin oluşmasını sağlamıştır. Haberlerdeki NATO vurgusunun sık olması da NATO ülkelerinin olası bir savaşı önleme gayeleridir. En sık anılan yabancı yöneticilerin isimleri de bahsedilen bu durumların bir sağlaması niteliğindedir. En çok ismi anılan yabancı yöneticinin Wilson olması İngiltere'nin Kıbrıs konusundaki önemini gösterirken, Sisco'nun da adının sık geçmesi ABD'nin görüşmelere katılma talebinin gazetelerdeki yansıması olarak yorumlanabilir. Ayrıca Waldheim ve Luns'un isimlerinin anılması da BM ve NATO’nun etkinliğinin göstergesidir. 
Türkiye özellikle İngiltere ile yaptığı görüşmeler neticesinde tüm dünyaya barış yanlısı olduğunu göstermiş ve amacının Kıbrıs'ta sulhu sağlamak olduğunu izah etmiştir. Bu uluslararası algı gerçekleştirilirken beraberinde bir de Kıbrıs için mekân tahayyülü oluşturulmuştur. Kıbrıs'ın önemini ifade eden söylemler Türkiye'de 1950'lerden sonra geliştirilmiş ve "Yavruvatan" tahayyülü ile zirveye ulaşmıştır. Fakat bu mekân tahayyülü Türkiye sınırları ile sınırlıdır. Yani uluslararası arenada Türkiye'nin Kıbrıs'a atfettiği önemin karşılığı bu kadar derin değildir. Yaşanan son süreç ise Türkiye'nin Kıbrıs'1 milli duygularla değil, demokrasi ve insan hakları bağlamında koruduğunu, sadece Türkleri değil Kıbrıslı Rumları da muhafaza etme gayesinde olduğunu göstermiştir. Bu tutum Türkiye'nin Kıbrıs'a yönelik "Yavruvatan" bakışından "Kurtarılması Gereken Mekân" ya da "Korunulması Gereken Mekân" konumuna geçmesi sağlanmıştır. Böylece Türkiye tüm dünyanın kabul edeceği bir Kıbrıs tasavvurunu kamuoyuna aktarmış ve Türkiye'nin eylemleri artık uluslararası camiada onaylanabilir noktaya ulaşmıştır. Bu yönüyle bakıldığı zaman milli dava, milli mesele gibi daha çok ulusal bakışa yönelik cümlelerdense daha gerçekçi bir bakış sergileyen Kıbrıs Sorunu ifadesinin kullanılması aynı amaca yönelik olarak düşünülebilir.

Özetle incelenen gazetelerin dört günlük birinci sayfa haberleri ile ilgili genel bir değerlendirme yaptığımızda haberlerin ifade edilen kilit kavramlar ile sunulması jeopolitik bir hamledir. Bu hamle sayesinde gazeteler aracılığı ile iç ve dış kamuoyuna mesajlar aktarılmıştır. $\mathrm{Bu}$ mesajlarla Türkiye parça parça bir Kıbrıs algısı oluşturmuştur. En önemli mesaj, sulh için yapılan mücadele mesajıdır. Türkiye her eylemini ada sulhu ve güvenliği için gerçekleştirdiğini ifade etmiştir. Diğer önemli mesaj darbenin Yunanistan tarafından yaptırıldığı mesajıdır. Ayrıca Yunanistan'daki antidemokratik yönetim şekli de siklıkla vurgulanarak, antidemokratik Yunanistan'ın demokratik Kıbrıs Cumhuriyeti'nde de antidemokratik bir yönetim arzuladığı aktarılmıştır. Bu mesajlar birçok ülke tarafından kabul edilmiş ve Yunanistan'a tepki gösterilmiştir. Böylece özellikle dış kamuoyuna suçludan yana olunmaması gerektiği mesajı verilmiştir. Gazetelerdeki yabancı basın haberleri uluslararası alandaki bu tepkileri Türk kamuoyuna da göstermektedir. Ayrıca Yunanistan'ın Garantör Devlet olma sıfatıyla Türkiye ve İngiltere görüşmelerine çağrılmaması İngiltere'nin de Yunanistan'ın darbeci kimliğini kabul edildiğini göstermektedir. Böylece başta ABD olmak üzere diğer ülkeler de Türkiye'nin yanında olmak durumunda kalmıştır. Dikkat çekilmesi gereken diğer bir mesaj ise NATO'nun durumudur. Türk gazeteleri haberlerinde sıklıkla NATO vurgusu yapmıştır. Türkiye'nin NATO için önemli olduğunu, Soğuk Savaşta Rusya'ya bir tampon konumunda olduğu hatırlatılmıştır. Türkiye'nin bu haklı çabasının desteklenmemesi durumunda Türkiye'nin NATO'nun dağılma ihtimalini bile göze alarak gerekirse Yunanistan ile savaşacağı anlatılmıştır. Böylece Türkiye Kıbrıs'a yapacağı müdahalenin hem gerekçelerini göstermiş hem de sonucunda oluşacak tepkilerin bertaraf edilmesini sağlamıştır. Seçimle iş başına gelen 37. Hükümetin Kıbrıs krizindeki tutumu Türk halkı tarafından olumlu karşılanmış ve süreç içinde önemli hiçbir tepki almamıştır. Halkın desteğini hisseden Başbakan Ecevit bu özgüvenle 8 Ağustos 1974 tarihinde ikinci Kıbrıs Harekâtını da düzenlemiştir. Ecevit, II. harekâttan sonra seçimlerden daha büyük bir zaferle çıkacağına olan inançla 17 Kasım 1974 günü 37. Hükümetten çekilerek, seçime gitme yolunu tercih etmiştir.

Demokratik rejimlerde iktidarlar seçimlerle gelir ve seçimlerle gider. İktidar devamlılığı için kamuoyu desteği şarttır. Bu nedenle iktidarların eylem ve söylemlerinde kamuoyu desteği alması gerekir. Türkiye de 1974 yılında Barış Harekâtını gerçekleştirirken kamuoyu desteğini almak için eleştirel jeopolitik bir yöntem kullanmış ve hem iç hem de dış kamuoyundan destek almıştır. Bu destek sayesinde harekât gerçekleştirilirken Türkiye'ye karşı hiçbir tepki oluşmamıştır. Başta Amerika olmak üzere birçok devlet bu yöntemi uzun yıllardır kullanmakta ve dünya kamuoyuna kendilerini izah etmektedir. Bu bir güçtür ve özellikle "yumuşak güç" kavramının daha da ön planda olduğu çağımızda değerli bir güçtür. Literatürde kitle iletişim araçlarında algı yönetimi ile ilgili birçok çalışma vardır. Fakat devlet eylem ve söylemlerini izah etmek için eleştirel jeopolitik bakışla gerçekleştirilmiş bir çalışmaya rastlanılmamıştır. Eleştirel 
jeopolitik ile ilgili yapılan çalışmalarda ise daha çok film, müzik, dergi, fotoğraf gibi tek bir öğe üzerinden değerlendirme yapılmıştır. Belirli bir dönemi, belirli bir eylemi, kitle iletişim araçlarındaki açık ve örtülü mesajlar üzerinden değerlendiren bir çalışmaya rastlanılmamıştır. Bu bakışın çalışmalarda daha sık yer alması söylemlerin altındaki amaçların araştırılması gerekmektedir. Birçok devlet bu gücü başka devletleri zayıflatmak, huzursuzluk çıkarmak amacıyla kullanmaktadır. Böyle bir durumda kamuoyunun algılarının açık olması ve alttaki mesajların anlaşılması için eleştirel jeopolitik bakışla kitle iletişim araçlarının değerlendirilmesi yapılmalıdır. Bu çalışmada ele aldığımız konu Kıbrıs Harekâtı konusudur fakat eleştirel jeopolitik tasavvurların yer aldığı birçok ileti internetin gelişmesiyle birlikte bireylere çok daha rahat ulaşmaktadır. Eleştirel jeopolitik bakış açısıyla yeni medya ve sosyal medya alanlarında yapılacak da çalışmalara ihtiyaç vardır.

\section{Extended Abstract}

This study aims to show how messages hidden between the lines of the mass media are transmitted to society. In democratic societies, the most important element necessary for political powers to maintain their power is public support. Political parties desire the continuity of their power by being re-elected in elections. Thus, political governments want to avoid ambiguous situations in their actions and attitudes that may cause public reaction or cause misunderstandings in the public. In addition, political governments aim to explain their actions and attitudes to the public in detail and to get their support. For this reason, they often use the mass media's strong public opinion potential to gain public support. This is why the Turkish government passed on various information to the public before carrying out the Cyprus peace operation on July 20, 1974. Through this information, it explained to the public the reasons, the need and the possible consequences of the operation it wanted to carry out. Thus, it carried out the Cyprus Peace Operation first with the support of the Turkish public and then the world public. This attitude of Turkey leads us to a critical geopolitical conclusion. The critical geopolitical thought that came to the spotlight after the 1990s tells us the power of governments to create public opinion by using mass communication tools with popular geopolitics. This study aims to reveal how the popular geopolitical method, which is a sub-branch of critical geopolitics, was used during the Cyprus Peace Operation.

In order to put forward critical geopolitical thought, Cumhuriyet Newspaper and Milli Newspaper, which were known for their closeness to the Government of Turkey at the time, were selected. In addition, Hürriyet and Milliyet newspapers, which were considered as mainstream newspapers with high circulation and not representing any ideology, were also included in the study. The first pages of these four newspapers have been analyzed. The duration of the analysis was decided as the four-day period between the coup against the president of the Republic of Cyprus Makarios and Turkey's operation in Cyprus. During this time, all the frontpage news about Cyprus was examined. Content analysis method was used as the review method. There is a fundamental reason for using content analysis method. Because it was desired to see if the frequency of the concepts being remembered and the perception that was desired to be created had some parallelism. While applying the content analysis method, first, the categories were determined and significant units serving these categories were created. The significant units were scanned one after the other in the text and the number of times they were repeated was determined. These determinations were distributed in tabular forms.

In the conclusion and discussion part of the study, the data obtained in the previous section were evaluated in a critical geopolitical reading. With the critical geopolitical reading, the data that were not expressed clearly in the news texts were revealed. Especially in newspaper news, the methods of creating identities, representations and visions were in detail. The Greek identity, Greek of Turkish root identity and Turkish identity formed in the news texts were discussed in depth. Before the coup took place, there was a process which transformed the "Greeks who kill the Turks" identity, into the "Greeks of Turkish root victims" identity, reported 
in the news until the coup took place described. Also, how Britain, Greece and Turkey, which are guarantors of the State of Cyprus, were transformed in the news texts are examined and the changes in these identities are explained in the process. In the formation of Turkish identity, it was seen that the use of "I/we" was made over the use of "other" that Edward Said often expressed in his idea of "Orientalism". It was understood that the guarantor status of Greece, which is seen as responsible for the coup action, was questioned and Greece was not included in negotiations between Britain and Turkey. Thus, it was seen that the guarantor identity of Greece over the Republic of Cyprus was dropped.

Changes in the representation of space, which is one of the important subjects of critical geopolitics, have also been observed in the news. The change in Cyprus's perception of space has been explained. The transformation of the perception of space presented to the Turkish public from the concept of " cub Homeland" to "the space that needs to be protected" was conveyed. Also, it is understood that the importance of Cyprus for Turkey's security is often emphasized and thus the perception of "strategic space" is created.

Another important subject mentioned was the Turkish and foreign leaders who were active in the preparation process of the Cyprus Operation. Bülent Ecevit, the Prime Minister of Turkey at the time, was the most mentioned administrator among the Turkish leaders. This, in turn, is insane because of the importance that Turkey attached to the Cyprus issue. It was also understood that one of the Turkish executives, Chief General Staff Semih Sancar, was mentioned much less than politicians. The reason for this situation is a clear expression of Turkey's pro "peace" policy, which was expressed throughout the Cyprus process.

The review showed that the most mentioned among the foreign leaders was Harold Wilson, the British Prime Minister of the time. Wilson's presence at the forefront was due to two reasons. The first is that it is a guarantor state, and the second is Turkey's willingness to do the operation together with Britain. In the analysis made over the names, it was seen that the US administrators of the period were also frequently mentioned. The result we saw in this situation is the importance given to the Cyprus issue by the USA. But in contrast, the frequency of which the USSR was mentioned is observed to be in considerable numbers. Considering the conditions of that period, a different result emerges at this point. This period was the Cold War period. The USA and the USSR were two rival powers. These two rival powers faced off on the Cyprus Issue also.

In addition, a different conclusion obtained from newspapers is that Turkish newspapers gain an advantage in creating public opinion by using the status of Greek leaders. In 1974, the administration in Greece was led by the junta that came to power with a coup. So, there it was an undemocratic administration. This undemocratic administration wants an undemocratic administration in Cyprus too as it is in their own country. These thoughts were expressed frequently in Turkish newspapers. This also was one of the reasons why Turkey's thoughts were accepted internationally.

The most important results of the Cyprus subject are the dimension of international relations. When evaluating the international dimension, it should be remembered that it was the Cold War period. The two NATO countries' conflict over Cyprus and the possibility of war was considered an international crisis. A serious effort has been made to resolve the Cyprus problem in a reasonable manner and as soon as possible for all parties. The most important evidence of this situation is the statements of NATO and the UN in newspaper reports. The Western Bloc countries, especially the United Kingdom and the United States, which were concerned about the dissolution of NATO, have tried to stop Turkey. The support of the USSR, the leader of the Eastern Bloc countries, to Turkey enabled the United States and Britain to also support Turkey.

In summary, Turkey created a perception of Cyprus piece by piece in the four days from the Makarios coup to the Peace Operation. First of all, it was conveyed to the Turkish public the 
need for an intervention in Cyprus. Possible consequences and the damages that Turkey will suffer when there is no intervention were explained. And to the world public, it was conveyed that Turkey, as a guarantor state, wants to re-establish the deteriorating order in Cyprus. It was explained that it is Turkey's duty as a guarantor to guarantee the safety of the Greek and Turkish people being slayed. Turkey's request for an intervention with Britain has shown that Turkey will not invade Cyprus. It also proved that Turkey will restore the order in Cyprus that was disrupted by Greece. With Turkey's decision not to discuss Cyprus issue with Greece, it also gives Greece a coup d'état identity in the international public.

\section{Kaynakça}

Açikses, E. ve Cankut, A. (2014). Kıbrıs meselesinin tarihsel gelişimi ve uluslararası hale gelme sebepleri. Turkish Studies International Periodical For The Languages, Literature and History of Turkish or Turkic 9(4), 1241-1259.

Akmaral, K. (2004). Kıbrıs Türkünü imhayı hedefleyen Akritas Planı ve Annan'a dek uzanan planlar süreciyle Kıbrıs. İstanbul: Bilge Karınca Yay.

Arğın, E. (2019). Siyasi partilerin 2019 yerel seçimlerinde Web sitesi kullanımı ve karşılaştırmalı analizi. Selçuk Üniversitesi Sosyal Bilimler Meslek Yüksekokulu Dergisi, 22(2), 397-404.

Anaz, N. (2012). Siyasi coğrafyada yeni eğilimler ve popüler jeopolitik. Anaz N. Özkan M. (Ed.) Batı medyasının Ortadoğu tasavvuru popüler jeopolitik, oryantalizm ve uluslararası ilişkiler. İstanbul: İlke Yayıncılık. 17-38.

Aşkan, H. ve Üzümcü, A. M. (2020). Soğuk Savaş Dönemi'nde Özgür Avrupa Radyosu'nu konu alan "Gerçekliğin Kuleleri" adlı kısa film üzerine inceleme. Anadolu Akademi Sosyal Bilimler Dergisi, 2(1), 71-92.

Bilgin, P. (2004). A return to 'civilizational geopolitics' in the Mediterranean? Changing geopolitical images of the European Union and Turkey in the Post-Cold War Era. Geopolitics, 9/2. 269-291.

Bulunç, A. Z. (2016). Kıbrıs Türk Halkının varoluşs savaşı ve Rauf R. Denktaş, Ankara: Kıbrıs Türk Kültür Derneği Genel Merkezi Yayını.

Cankurt, A. (2013). Türkiye Cumhuriyeti Hükümetlerinin Kıbrls politikaları ve kamuoyuna yansımaları (1955:1964). Fırat Üniversitesi Sosyal Bilimler Enstitüsü Yayımlanmamış Doktora Tezi, Elazı̆̆.

Çakmak, Z. (2009). Kıbrıs'ta isyan. İstanbul: IQ Kültür Sanat Yayıncılık.

Çetin, B. N. (2017). Toplumsal bir eylem biçimi olarak Traktör Futbol Takımı bağlamında jeopolitik tasavvur oluşturma süreci. The Journal of Academic Social Science Studies, 9 (Number: 62), 317-331.

Denktaş, R. (1999). Rauf Denktaş’ın hatıraları 9 (1973:1974). İstanbul: Boğaziçi Yayınları.

Dodds, K. (2000). Geopolitics in a changing world. England: Published by Pearson Education Limited.

Dodds, K. (2005). Global geopolitics a critical introduction. England: Pearson Education Limited.

Dodds, K. (2008). 'Have you seen any good films lately?' Geopolitics, international relations and film. Geography Compass, 2(2), 476-494.

Ekincikli, M. (1999). Kıbrıs'ın Türk hâkimiyetine geçişini hazırlayan siyasi, askeri ve sosyal şartlar. İkinci Uluslararası Kıbrıs Araştırmaları Kongresi Bildiri Kitabı, Gazimagosa, KKTC: Doğu Akdeniz Üniversitesi Kıbrıs Araştırmaları Merkezi Yayınları: 7. 
Erdoğru, A. M. (1999). 18. yüzyıl sonlarında Kıbrıs'ta Avrupalı konsoloslar ve tercümanları, İkinci Uluslararası Kıbrıs Araştırmaları Kongresi Bildiri Kitabı, Gazimagosa, KKTC: Doğu Akdeniz Üniversitesi Kıbrıs Araştırmaları Merkezi Yayınları: 7.

Erzen, A. (1963). Tarihi ve sosyal bir dava olarak Kıbrıs Meselesi, Otuzuncu Konferans https://dergipark.org.tr/tr/download/article-file/100920

Gerçel, A. (1999). Kıbrıs tarihinde göçler, Gazimagosa, KKTC: Doğu Akdeniz Üniversitesi Kıbrıs Araştırmaları Merkezi Yayınları: 7.

Günal, A. (2019). ABD'nin 1974 Kıbrıs Askeri Darbesindeki rolü. OPUS Uluslararası Toplum Araştırmaları Dergisi, 10(17), 2168-2207.

Hasgüler, M. (2007). Kıbrıs'ta Enosis ve Taksim politikalarının sonu. İstanbul: Alfa Basın Yayım Dağıtım.

İsmail, S. (1998). 150 soruda Kıbrıs Sorunu. İstanbul: Kastaş Yayınevi.

Kasım, K. (2007). Soğuk Savaş Dönemi Sonrası Kıbrıs Sorunu. Gazi Akademik Bakış, (01), $57-$ 73.

Kılıçoğlu, Ç. (2010). Albaylar Cuntası Döneminde Yunanistan’ın Türkiye Politikası (19671974). Ankara Üniversitesi Türk İnkılâp Tarihi Enstitüsü Yayımlanmamış Yüksek Lisans Tezi, Ankara.

Kurşun, Z. (1999). Buhran Yıllarında Kıbrıs'ın Durumu ve Rumlar'ın Adayı Yunanistan'a İlhak Çabaları (1878:1914). Ikkinci Uluslararası Kıbrıs Araştırmaları Kongresi Bildiri Kitabı, Gazimagosa: KKTC: Doğu Akdeniz Üniversitesi Kıbrıs Araştırmaları Merkezi Yayınları:7, $1-8$.

Manisal1, E. (2000). Dünden bugüne Kıbrls. İstanbul: Cumhuriyet Yayınları.

Manizade, D. (1965). Baştan sona Kıbrıs gerçeği. İstanbul: Hüsnütabiat Matbaası.

McQuail, D. ve Windahl, S. (1994). Kitle iletişim çalışmaları için iletişim modelleri, (Çev: Dağtaş, B. Demiray, U.). İstanbul: Sağlık ve Bilimsel Araştırmalar Çalışmalar Vakfı Yayınları.

Mütercimler, E. (2003). Satılık Ada Kıbrıs Barış Harekâtının bilinmeyen öyküsü. İstanbul: Toplumsal Dönüşüm Yayınları.

Ó Tuathail, G. (1998). General introduction: Thinking critically about geopolitics, (Der. Dalby, S. Routledge, P. Tuathail, Ó. G.). The geopolitics reader, Londra ve New York: Routledge.

Ó Tuathail, G. (1999). Understanding critical geopolitics: Geopolitics and risk. The Journal of Strategic Studies, 22(2-3), 107-124.

Ó Tuathail, G. ve Agnew J. (1992). Geopolitics and discourse: Practical geopolitical reasoning in American foreign policy. Political Geography, 11(2), 190-204.

Qasımlı, M. (2013). Türkiye-Sovyet Sosyalist Cumhuriyetleri Birliği ilişkileri, (Çev: Alpertunga A.). Ankara: Atatürk Araştırma Merkezi Yay.

Sander, O. (2014). Siyasi tarih: 1918-1994. Ankara: İmge Kitabevi.

Sonyel, R. S. (2014). Gizli belgelerle Kıbrıs Sorunu kaygılı yıllar (1974-1975). Ankara: Atatürk Araştırma Merkezi.

Şener, B. (2017). Jeopolitik uluslararası ilişkilerde insan, devlet, coğrafya ve zaman etkileşimi üzerine bir giriş. Ankara: Barış Kitap.

Tezkan, Y. ve Taşar, M. M. (2013). Dünden bugüne jeopolitik Dünya ve Türkiye. İstanbul: Ülke Yayınları. 
Tirben, E. G. (2009). Dünyaya yeni bir bakış: Eleştirel jeopolitik, (Der. Palabıyık M. S.). Batı'da jeopolitik düşünce. Ankara: Orion Kitapevi.

Tiryakioğlu, F ve Top, D. (2010). Sayfa tasarımı ve kurumsal kimlik oluşturma: Türkiye'deki ulusal gazetelerin birinci sayfaları üzerine bir araştırma, Selçuk İletişim, 6(3), 137-146.

Turan, S. (2009). Jeopolitik açıdan Kıbrıs'ın Türkiye için önemi ve realpolitik bağlantısı (1950:1960). I. Uluslararası Kıbrıs Sempozyumu Bildiri Kitabı. Ankara: Kıbrıs Türk Kültür Derneği.

Pınarbaşı, G. (2020). Kültür endüstrisi bağlamında New Age uygulamalarından-inançlardan astrolojinin Facebook dolayımlı içerik analizi (2018-2019). Maltepe Üniversitesi İletişim Bilimleri Anabilim Dalı Yayımlanmamış Doktora Tezi, İstanbul.

Yayla, T. (2014). Diplomat Hasan Esat Işık'ın biyografisi (1916-1989), Yıldız Teknik Üniversitesi Sosyal Bilimler Enstitüsü Yayımlanmamış Yüksek Lisans Tezi, İstanbul.

Yeşiltaş, M. ve Durgun, S. (2015). Coğrafya ve jeopolitiği tartışmak: Eleştirel bir derleme. Yeşiltaş M. Durgun S. Bilgin P. (Ed.) Türkiye dünyanın neresinde, İstanbul: Koç Üniversitesi Yayınları, 9-35.

Yeşiltaş, M. (2016). Türkiye'de ordu ve jeopolitik zihniyet. Ankara: Kadim Yayınları.

Yıldırım, B. (2015). İçerik çözümlemesi yönteminin tarihsel gelişimi uygulama alanları ve aşamaları. (Der. Yıldırım B.). İletişim araştırmalarında yöntemler: Uygulama ve örneklerle, Konya: Literatürk Akademia, 105-155.

\section{Gazeteler}

Cumhuriyet Gazetesi 23.04.1974 / 16.07.1974 / 17.07.1974 / 18.07.1974 / 19.07.1974

Milli Gazete 23.04.1974 / 16.07.1974 / 17.07.1974 / 18.07.1974 / 19.07.1974

Milliyet Gazetesi 22.04.1974 / 16.05.1974 / 16.07.1974 / 17.07.1974 / 18.07.1974 / 19.07.1974

Hürriyet Gazetesi 16.07.1974 / 17.07.1974 / 18.07.1974 / 19.07.1974

\section{İnternet Kaynakları}

https://www.fpri.org/contributor/joseph-sisco/, Erişim Tarihi 18.11.2020.

https://www.biyografi.info/kisi/henry-kissinger, Erişim Tarihi 18.11.2020.

https://www.bbc.com/turkce/haberler-dunya-50826215, Erişim Tarihi 15.11.2020.

https://www.dersimiz.com/bilgibankasi/kurt-waldheim-kimdir-hakkinda-bilgi-6403, Erişim Tarihi 20.11.2020.

https://kimdirkimdir.com/joseph-luns-kimdir/, Erişim Tarihi 20.11.2020.

https://www.hurriyet.com.tr/gundem/1974-te-ingiltere-ile-savasa-girmemize-ramak-kalmis37632, Erişim Tarihi: 20.11.2020.

https://www.bilgiustam.com/abd-baskani-richard-nixon-kimdir/, Erişim Tarihi 20.11.2020.

https://www.milligazete.com.tr/bilgi/kurulus, Erişim Tarihi 15.11.2020.

https://www.biyografya.com/biyografi/14341, Erişim Tarihi 15.11.2020.

https://tr.wikipedia.org/wiki/Mill\%C3\%AE_Gazete, Erişim Tarihi 15.11.2020.

https://tr.wikipedia.org/wiki/Bat\%C4\%B1_Bloku\#: :text=Bat\%C4\%B1\%20Bloku\%20veya\%20

Kapitalist\%20Blok,\%22Bat\%C4\%B1\%20D\%C3\%BCnyas\%C4\%B1\%22\%20tan\%C4\%

B1m\%C4\%B1n\%C4\%B1\%20kullanmaktayd\%C4\%B1lar., Erişim Tarihi 15.11.2020. 


\section{İNIF E-DERGi}

Kasim 2021, 6(2), 386-408.

https://www.nato.int/nato_static_fl2014/assets/pdf/2020/6/pdf/What_is_NATO_tur_20200507.p df, Erişim Tarihi 10.11.2020.

https://europa.eu/youth/eu/article/63/3024_tr, Erişim Tarihi 10.11.2020.

Araş̧ırmacı Katkı Oranı: Araşstırmacılar çalışmaya eşit oranda katkı sunmuştur.

Destekleyen Kurum/Kuruluşlar: Herhangi bir kurum/kuruluştan destek alınmamıştır.

Çıkar Çatışması: Herhangi bir çıkar çatış̧ası bulunmamaktadır. 